\title{
11 Tools of Economic Activity in Early Imperial China
}

\section{Introduction}

This chapter considers major sets of tools in the form of structural and physical institutions that shaped the economic activities of various actor groups that have been discussed in chapter six. Many of these tools are intertwined with the power of state institutions, even though they also relied on other supporting factors to varying degrees. In any case, their socioeconomic effects typically went far beyond the functions primarily associated with them.

The fiscal regime of the early imperial state is one obvious example. With its thorough organizational capacity, it strongly affected people's economic behavior and broader socioeconomic structures through the ways in which revenues were collected and redistributed. Among others, changes in fiscal policies were also strongly tied to monetization processes, in the sense that they both reacted to and furthered the latter by increasing the share of monetary extraction. The effects of increased monetization, however, went far beyond the interests of state actors by substantially facilitating economic transactions in which a wide range of social groups participated.

Law is another tool that is deeply connected to state authority. Under a relatively standardized judicial system, early imperial law bore a strong potential for reducing uncertainties and negotiation costs, especially with regard to property claims. Reduction of negotiation costs across larger spaces can further be associated with certain spheres of standardization, e.g., of weights and measures. Additionally, the relatively standard use of the Chinese language and particularly the script, as well as the wide spread of sumptuary patterns, both of which were supported by administrative structures and state-promoted mobility of officials and common people, created further conditions for increased connectivity and for the use of mass production techniques.

Increased connectivity and the mobility of goods in particular further depended heavily on the network of physical infrastructure. In the form of both natural and artificial waterways as well as both preexisting and newly established overland routes, the early imperial network may have been more efficient than had previously been assumed with regard to travel speeds and its suitability for long-distance transport. Finally, this chapter will consider certain examples of technological devel-

Note: I would like to thank Armin Selbitschka for valuable comments on an earlier draft of this chapter.

○ Open Access. () 2022 Kathrin Leese-Messing, published by De Gruyter. (cc)BY-NC-ND This work is licensed under the Creative Commons Attribution-NonCommercial-NoDerivatives 4.0 License.

https://doi.org/10.1515/9783110607642-016 
opments that, in combination with various forms and degrees of state promotion, shaped the production and spread of certain products, from metal implements of daily use to luxury textiles.

\section{Fiscal Regime}

\section{II.1 Introduction}

The early imperial fiscal regimes evolved from the policies that characterized the bellicose centuries of the Warring States period (475-221 вCE). The fiscal system of the Qin state has been branded by von Glahn as "military-physiocratic."1 It largely relied on in-kind, agrarian-based taxation and massive forced labor, and had essentially been designed to finance warfare and the accompanying measures of rationalization and bureaucratic centralization. It was characterized by land-allocation by the state, ${ }^{2}$ an intensive exploitation of a narrowly circumscribed tax base, meticulous systems of accounting and household registration, high monitoring costs, a comparatively low level of monetization, irregular levies, and frequent changes in tax rates. It was further characterized by a determined preclusion of private parties from the benefits of resource extraction and, in the long run, by a lack of options for the agents (i.e., local officials and elites) to cooperate with the principal (i.e., the central government) to secure the former's loyalty. ${ }^{3}$

Qin's vast and rapid imperial expansion toward the east and southeast required the integration of regions with more monetized markets as well as powerful mercantile and land-based elites. This made reforms of the fiscal system inevitable, attempts at which the Qin regime was not able to adequately implement during its short reign. The following Han regime took over many elements of the Qin fiscal regime, including its system of accounting and household registration. But it also changed it in some fundamental ways. The Han expanded the tightly circumscribed tax base of the Qin by recognizing private land tenure and retracting land-allocation schemes. Furthermore, it gradually revised the inherited fiscal system by advancing its monetization level, building up a fixed-rate, low-tax regime, reducing monitoring costs, and creating the conditions for an 'imperial consensus' between the central government and local elites. ${ }^{4}$ Especially during phases of border conflict and impe-

1 Von Glahn 2016, 85; 2020, 10-14.

2 Before its massive eastward conquests, Qin expansion often meant colonization of territory, in which newly measured plots of arable land could be allocated to settlers, which also facilitated taxation.

3 Korolkov 2021b and Korolkov 2020, 49-142 offer detailed, up-to-date studies of the Qin fiscal system.

4 Korolkov 2021b, 232-243. 
rial expansion, additional means of securing fiscal revenue were introduced, which von Glahn has termed "mercantilist." 5 While some of these were ad hoc measures that would soon be withdrawn, others - such as the state monopolies on salt and iron - came to be institutionalized and supported the fiscal system for longer terms.

Estimates of the annual imperial revenue, based on both excavated local records and transmitted figures, vary considerably. Scheidel, for instance, suggests they may have amounted to around 10-12 billion in cash during late Former Han times, which would have equaled approximately 2.1-3.7 million tons of wheat. He concedes it may have been somewhat more in the case that some form of property taxes still existed at that time. ${ }^{6}$ Neglecting this possibility, this estimate suggests the Han imperial revenue came close to that of the Roman Empire (2.6-3.5 million tons of wheat) and featured roughly the same rates of annual per capita revenue (37-50 vs. 35-62 kg of wheat). ${ }^{7}$ Nevertheless, other estimates, such as that proposed by Yamada, suggest a much higher total revenue with a value of almost 19 billion coins, with close to half of it being collected in coin and the other half in kind. ${ }^{8}$ Since many pieces of information that lead to both of these estimates are highly speculative, the question about the extent of their accuracy must remain open. The same measure of caution must be applied to estimates of the relative portions that individual income sectors contributed to the total state revenue, some of which will be presented below.

In general, the available evidence conveys the impression of a highly developed and institutionalized administrative fiscal system. One characteristic of the Former Han fiscal system in particular is its relatively clear separation between revenues of the emperor's privy purse (the 'Lesser Treasury,' Shaofu 少府) and public funds. With this separation being linked with a "precise, centralized planning of taxation and expenditure to satisfy the state's commitments to good governance, including defense of the realm and the economic welfare if its subjects," von Glahn suggests that the "institutional apparatus of the fiscal state already was a defining feature of governance in the first Chinese empires."9

\section{II.2 Revenues in Kind and Labor}

\section{II.2.1 The Land Tax}

The Han government possessed imperial lands by itself, which produced in-kind revenues through agriculture, forestry, and fishing. They went to the emperor's

5 Von Glahn 2016, 118; 2020, 14-17.

6 On property taxes, see sec. II.3.3 below.

7 Scheidel 2015, 151-156, 163-164.

8 Yamada 1993, 653-658.

9 Von Glahn 2020, 9. On the division between the public and privy purse, see further Bielenstein 1980, 43-69; Katō 1952; Zhu and Xia 2013. Yamada estimated an annual of 2.66 billion coins reve- 
privy purse but were probably marginal in relation to the total state revenue. ${ }^{10}$ The largest source by far of in-kind state revenue consisted of extractions from free peasant households. These agricultural taxes had already provided the means for the newly risen elite to defeat the old, often city-based nobles during the centuries predating the Qin unification. The fiscal and administrative institutions that the early empires inherited were thus primarily made for extracting resources from farmers rather than from urban residents. ${ }^{11}$

Accordingly, the primary tax levied by the Qin and probably also the Han state was the land tax (lit. 'field tax,' tianzu 田租). Even though its share in the total fiscal revenue decreased, it remained its most important element throughout the early imperial period..$^{12}$ It was collected per household and was typically paid in grain. Nominally a variable output tax levied as a percentage of the harvest, during Han times it appears in practice to have been a fixed input tax levied on the size of the land multiplied by a quota of an assumed average produce. This made state income more predictable while laying the risk of crop failure on the taxpayers' shoulders. ${ }^{13}$ Furthermore, it likely stimulated investment in their land's productivity. The assumed average produce was defined according to the quality of the taxed land, which was classified into three fertility grades. ${ }^{14}$ Throughout the Han period, the

nue to have entered the privy purse, in comparison to ca. 16.32 billion coins to have entered the public funds. See the table in von Glahn 2016, 117. However, many uncertainties and inconsistencies in transmitted figures are involved in the comparison of these revenues. See, for instance, a summary of some of these problems in Scheidel 2015, 152.

10 Yamada suggests them to have amounted to 300 million coins. See the table in von Glahn 2016, 117.

11 Lewis 2015, 294.

12 Most scholars assume that the land tax was still contributing the largest part to the Han Empire's fiscal revenue. As a concrete example, Yamada's estimates suggest that they amounted to an equivalent of 7 billion coins out of a total of about 19 billion coins. See the table (based on Yamada's estimates) in von Glahn 2016, 117. On the development of the land tax from Qin to Han times, see also Z. Yang 2008.

13 The 'learned scholars' in Yantie lun 15 clearly express this point: "Although the field [tax] is [nominally] one-thirtieth, it is paid according to the acreage. Thus in good years, when the grain lies about in abundance, the actual exaction would be [too] small, while in bad years with famine rampant, the full stipulated amount would yet be demanded” 田雖三十, 而以頃畧出稅, 樂歲粒 米狼戻而寡取之, 凶年饑饉而必求足. Yantie lun jiaozhu 15.191, trans. Gale 1967, 94 (with modifications). See also Hsu 1980, 72-73, including n. 36 with references to studies arguing that the land tax may still have been an output tax after all (which it indeed had been originally, during Warring States times).

14 This classification was introduced at some point during the Former Han period. As for the preHan period, excavated Qin documents suggest that Qin tax rates were adjusted annually according to actual crop conditions, which went along with high monitoring costs. This system served the goal of exploiting higher portions of yields from a spatially circumscribed fiscal base for which the government was able to attain detailed knowledge. In the other pre-imperial states in the east, the scarce available evidence suggests that their tax systems may have been more similar to the Han system in this regard, i.e., relying on fixed tax rates. See Korolkov 2021b, 212. 
quota changed several times, but by far the most common rate was a mere onethirtieth. ${ }^{15}$ The actual amounts of grain levied upon a certain portion and quality of land are, however, unknown. The grain collected via the land tax was stored in state granaries and redistributed in the form of parts of officials' salaries, rations for conscripts, convicts, and slaves, as well as famine relief and feasts.

\section{II.2.2 Labor Extraction from Conscripts, Convicts, Slaves, and Debtors}

The early empires' reliance on forced labor was largely a legacy of traditions that had characterized the Warring States and the pre-imperial state of Qin in particular. Both the circumscribed topography of its heartland, the 'area within the passes' (Guanzhong 關中), and its economy's belated monetization in comparison to its eastern neighbors had favored direct management of people's labor by the Qin state, which has ever since been notorious for its large-scale labor projects. ${ }^{16}$ With its vast imperial expansion eastward, both of these factors became less relevant. The extensive system of labor extraction that the Han inherited from the Qin resulted in an oversupply of labor resources during certain times and certain spaces. The Han government reacted to this by transforming these resources into forms that better met their variable, context-dependent needs. Demand-driven commutation of labor duties into cash payments can, therefore, be observed as a general trend in the Han government's approach to its labor regime.

Both the Qin and Han regimes levied civilian and military labor taxes on their population. Under Han rule, all young men were liable for two years of military service (one in their localities and one at the capital or frontier), as well as annual training sessions. Furthermore, civilian labor service of one month per year was theoretically owed by all males and females between fifteen and sixty-five. In order to minimize harm to agricultural output and procreation, it was predominantly exacted during times of little demand for agricultural labor, and duties for pregnant and nursing women were reduced or paused. Generally, women's assignments were probably mostly local, whereas men's labor duties often included work away from home. Certain honorific ranks furthermore went along with reduction of or exemp-

15 General Qin rates are unknown. Excavated Qin documents suggest an average tax rate of 8.61 percent (about one-twelfth) of the produce for the Qin county of Qianling (W. Chen 2012, 345347, tablet 8-1519; Korolkov 2021b, 248, n. 30). At the beginning of the Han dynasty, the rate reportedly was one-fifteenth. After a few decades of Han rule, grain surpluses reportedly allowed for a remission of the tax between 168 and 156 BCE. For the rest of the Former and Later Han dynasties, the rate seems to have been one-thirtieth, with a short interruption during and shortly after the civil war following Wang Mang's 王莽 (r. 9-23 CE) reign, for which sources mention an emergency rate of one-tenth. Hanshu 24.1135; Swann 1950, 171-172; Lewis 2015, 285-286.

16 Korolkov 2021b, 206. 
tion from conscript duties. ${ }^{17}$ Labor conscripts were employed in a variety of tasks, ranging from heavy work in construction projects and transport to skilled handicraft and monthly shifts as administrative functionaries. ${ }^{18}$

Over the course of the Han period, however, both conscript labor and military service obligations were increasingly replaced by cash payments, which could be deployed more flexibly on the basis of momentary demands and to hire long-term professionals. The originally unofficial, private arrangement of substituting labor duties, which was eventually institutionalized during the Former Han period, was an important step in this development. ${ }^{19}$ Even though the available evidence is not quite clear on this point, it appears that labor service and poll taxes came to be merged in local taxation documents, suggesting that the two became convertible. ${ }^{20}$ This would have provided a flexible opportunity for local officials to extract only the labor power needed at a certain point of time while commuting redundant labor levies to cash payments. Later in the Former Han period, the state introduced a 'tax [substituting] a term [of conscript labor]' (gengfu 更賦), the income of which could also be used to hire laborers flexibly. ${ }^{21}$ Regular military service duties may have been abolished in $32 \mathrm{CE}$, but this point is not entirely clear. ${ }^{22}$

The fiscal system forced producers to make fuller use of their labor capacities either by performing services during agricultural off-peak seasons or by developing means to earn the required monetary sum on the market. It may therefore be assumed to have contributed to a modest increase in per capita production. ${ }^{23}$ In this regard, however, one also has to acknowledge contemporary critics' warnings that the various tax and service burdens added up to a dangerous overstretching of peasants' labor capacities. ${ }^{24}$

Convict laborers ( $t u$ 徒 or xingtu 刑徒) were yet another indispensable functional element of both the state-sector economy and its administration. In both the Qin

17 Von Glahn 2016, 101-105; 2020, 11.

18 Korolkov 2020, 96-106.

19 Pre-imperial Qin law already permitted substitution of a person's labor debts (for unpaid fees, fines, or outstanding debts in coin or kind) with labor by another person. This encouraged the development of a market for hired labor substitutes, whose wages then depended on market conditions. Shuihudi Qin mu zhujian zhengli xiaozu 1990, 51 (slips 137 and 140); Hulsewé 1985a, 68-69; Korolkov 2021a; Cang 2012, 157. On the hiring of substitutes for military service at the frontier, see G. Xie 1989.

20 E.g., Hsing 2014, 173-174.

21 Watanabe 2010, 94-100; von Glahn 2016, 125; Korolkov 2021b, 234.

22 Lewis 2015, 286-287; Leese-Messing, vol. 1, ch. 12.A, 182-183. The monetary revenue from commutation taxes is hard to estimate but could have reached hundreds of millions during certain phases. Scheidel 2015, 154.

23 Bang 2009, 112.

24 There are many examples of such criticism. See, for instance, the memorials by Chao Cuo 昆錯 (ca. 200-154 BCE) and Dong Zhongshu 董仲舒 (179-104 BCE), as well as the decree by Wang Mang 王莽 (r. 9-23 CE) translated in Hsu 1980, 160-166. 
and Han judicial systems, penal servitude was among the most frequent forms of punishment, and replenishing the pools of convicts for state labor projects must be considered as an important target of legal codes. ${ }^{25}$ Convicts, too, could be employed in a wide variety of tasks, including those that demanded certain skills, such as in craft workshops. During Qin times, two of their central tasks appear to have been clearing new fields and working on state-managed farms, but the importance of state-managed farms and the respective demand for labor declined considerably during late Qin and early Former Han times. ${ }^{26}$ Transmitted Han texts often associate convicts with heavy and dangerous labor, including construction and mining, and the military. The social status and terms of employment of convicts did, however, vary more widely than one might expect. Evidence from the Qin period suggests that numerous convicts maintained a certain extent of economic agency, engaged in private craft and market activities as wageworkers, and were employed on a parttime basis, which saved operational and provisioning costs for the state. ${ }^{27}$ The documents further testify to the local governments' interaction with private markets for dependent laborers either by selling or leasing out surplus convict workforces or by buying slaves from private owners to integrate them into convict labor gangs. ${ }^{28}$ The state's attempts at making the penal service system more flexible and cost-effective are thus already visible during this early stage. During Former Han times, a 'standing army' of convicts must increasingly have been a thorn in the side of fiscal budgeteers with regards to its inflexibility and high costs of maintenance and coercion. At any rate, the state's efforts to make the system more flexible and less costly are obvious from various sources, for instance by a change from lifelong to fixed-term servitude, and by frequent announcements of amnesties. ${ }^{29}$

Government institutions also used male and female slaves ( $n u$ 奴 and bi 婢 in Han terminology). ${ }^{30}$ Slaves could be acquired through the penal system, which sys-

25 On penal servitude, see Miyake 2016a; 2016b; Han 2011; Korolkov 2015; 2020, 307-427; BarbieriLow 2007, 227-245.

26 Korolkov 2020, 122-128.

27 Korolkov 2020, 362-367.

28 The legal ambiguity of convict and slave statutes as suggested by such transfers has long been a matter of debate. In a recent attempt to explain this ambiguity, Korolkov argues that transfers of Qin convicts to private slavery actually consisted of a "conditional transfer of rights to labor, rather than full-fledged private ownership," and that this phenomenon was based on the "state's claim to a degree of control over all unfree individuals regardless of who possessed the right to their labor," Korolkov 2021b, 216-217.

29 Miyake 2016a, 147-151; Korolkov 2020, 327-332, 406-408, 421-423. That convict laborers kept being used on considerable scales in ironworks and construction projects even during the Later Han period, however, is suggested by finds of mass graves of convicts (who evidentially came from all over the empire) near Luoyang and a reference to road building (for the Bao-Ye road in $63 \mathrm{CE}$ ) using thousands of convicts from different commanderies. Wagner 2001, 49-52; Barbieri-Low 2007, 237-242.

30 One contemporary critic of government expenditure, Gong Yu 貢禹 (ca. 123-44 BCE), mentioned the number of one hundred thousand state slaves, but the conspicuously round figure as well as 
tematically forced family members of people charged with serious crimes into slavery. Furthermore, private slaves could enter the government labor force via confiscations from their law-breaking owners or, as mentioned, simply by buying them from private owners. Enslavement of war captives, by contrast, does not seem to have played a big role. Slaves often are associated with tasks similar to those of convicts, even though especially after the limitation of the latter's terms of service, their often lifelong status may have rendered them more likely than other forced laborers to be used in service capacities and in skilled tasks. Frequent references to male and female slaves in association with service tasks in palaces, for instance, as well as criticism of idle government slaves who just "sit and are stipended with clothes and food" or "loaf about without work" may be an indication of this trend. ${ }^{31}$

The state's labor pool was further expanded by state debtors. Commoners unable to pay fines or fees, repay money or grain loans, or return draft animals or agricultural tools borrowed from local governments could be required to work off their debts. By means of a sophisticated, empire-wide accounting system, these debts could further be transferred over large distances from one local government to another in the case of the debtor's change of residence (for instance, for military service at the frontier). Even more obviously than in the case of commutable labor taxes, the system of debtor labor required a concept of quantifiable labor that enabled fungibility between labor time and other values such as cash and grain on the basis of a "uniscalar system of numerical valuation," 32 which is likely to have been a facilitating factor in the subsequent monetization of labor services in particular and of the Han fiscal system in general.

\section{II.3 Revenues in Coin}

\section{II.3.1 The General Trend of Monetization of the Fiscal System}

Even though the Qin regime already extracted some revenues (e.g., commercial taxes) in cash, these were still marginal compared to the revenues collected in kind. The first decades of Han rule were characterized by a relatively weak central government that had to allow both administrative and fiscal decentralization. It also tolerated private coin casting, which resulted in a significant expansion of the volume of circulating coin. Eventually, the government introduced a state monopoly on coinage, under which private coin casting was prohibited and state coinage facili-

the author's highly critical stance have rendered this high figure unreliable. See, e.g., Wilbur 1943, 397; Scheidel 2017, 147.

31 Wilbur 1943, 221-236; Barbieri-Low 2007, 249-256. On the status of slaves, see further Yates 2001; 2014.

32 Korolkov 2020, 375. On the system of convict labor, see also Miyake 2016a. 
ties produced copper coins on a massive scale. Even though the direct revenues from these facilities were marginal and never evolved into a major contribution to the Han state's annual revenue, ${ }^{33}$ the introduction and maintenance of the monopoly on coinage was of major importance in both political and larger economic terms (see sec. II). The increasing level of coin use and imperial expansion were concomitant with an increasing monetization of the fiscal system and a transition to more flexible revenues, not only in the context of labor extraction, but also with regard to other forms of taxation.

\section{II.3.2 Capitation Taxes}

Neither transmitted texts nor hitherto excavated Qin manuscripts refer to a capitation tax (suanfu 算賦) under the Qin regime. According to the Hanshu, this tax was introduced by the founding emperor of the Han dynasty. It is the clearest sign of the Han fiscal regime's increased level of monetization and was also related to the development of a professional bureaucracy whose members were paid fixed salaries that consisted largely of cash payments. ${ }^{34}$ The capitation tax was levied in cash on both men and women between the ages of fifteen and fifty-six. During the first decades of Han rule, the tax did not yet have a fixed annual rate but was apparently assessed according to the incidental monetary needs of local governments. After its fixation at some (unknown) point of the Former Han period, ${ }^{35}$ the usual rate for adults was 120 cash per year, corresponding to the price of about 20 liters (one picul) of grain during the second century BCE, and somewhat less afterward. Higher rates are mentioned for merchants (doubled rate) and unmarried women between 15 and 30 years of age. There were reduced rates for households with members older than 80 (exemption of 240 cash) and for new mothers, who were allowed a threeyear remission during some phases of Later Han. Options for paying the capitation tax in grain and beans are occasionally reported in emergency cases. ${ }^{36}$ There was a variant of the capitation tax (called koufu 口賦) levied on children between the ages of three (or later, seven) and fourteen with a usual rate of 20 cash per year. ${ }^{37}$ The

33 Yamada's estimate (as presented in von Glahn 2016, 117) amounts to 154 million coins per year during Former Han times. See also Scheidel 2015, 152.

34 Hanshu 1A.46; However, some monetary levies that are sporadically mentioned in texts with regard to Qin times under the designation of $f u$ 賦, appear to have been irregular levies on either individuals or households and may be seen as precursors to the Han capitation tax. Korolkov 2021b, 207, with n. 14 on 246.

35 Korolkov 2021b, 239.

36 Hanshu 7.228; 232, trans. Hsu 1980, 140-141.

37 For the capitation taxes, see Lewis 2015, 286. Other than the capitation tax on adults, the revenues from the tax on minors went to the emperor's privy purse. 
capitation taxes are commonly assumed to have contributed the largest share to the state's in-coin revenue. ${ }^{38}$

\section{II.3.3 Commercial and Property Taxes}

During Qin times, commercial taxes belonged to the state's few sources of cash. Qin statutes required trade to be mainly conducted at official markets (shi 市) by registered traders, who were - like farmers - enrolled in groups of five for mutual surveillance and responsibility. ${ }^{39}$

During Han times, commercial taxes including the annual market tax (shizu 市租) extracted from registered traders at marketplaces and authorization fees (zhi 質) levied on big-ticket sales such as slaves, horses, or cattle continued to be important sources of cash revenue. While the shizu had long been interpreted as a fixed tax in the form of an annual market stall rent, excavated documents suggest that it might rather have been a variable tax on the value of goods sold. A Former Han statute demands marketplace traders to self-report their tax liability, probably in reference to the market tax. The rate of this tax remains unclear. ${ }^{40}$

During Emperor Wu's 武 (r. 141-87 BCE) reign, when the government desperately needed new revenues for its military expenses, taxation of people engaged in commerce and moneylending was extended by introducing a property tax on all their assets at a rate of six percent and half the rate for artisans. ${ }^{41}$ Carts and boats exceeding a certain size were taxed separately at a rate of 120 cash per vehicle, with merchants' carts being taxed at double the rate. Property taxes for other people existed as well at lower but still considerable rates of 1-2 percent. Evasion of property taxes was subject to heavy punishment, which could include confiscation of property, banishment, and enslavement of family members. The new or elevated taxes seem to be particularly meant to extract wealth from nonregistered traders. The high rates imposed on traders' and moneylenders' property must have amounted to a substantial addition to the imperial revenue, but may also have led to a high degree of dissatisfaction, tax evasion, and possibly a regression of trading activities. It is unclear for how long the Han government was able to maintain these taxes,

38 In Yamada's estimates, they amounted to more than 4 billion coins to the total of approximately 19 billion, with the latter including in-kind revenues (see the table in von Glahn 2016, 117).

39 See also Leese-Messing, ch. 6, VII and VIII, this volume.

40 Korolkov 2020, 113-115. For the legal statute, see Barbieri-Low and Yates 2015, 722-723 (no. 2 of the "Statutes on [Passes and] Markets"). Shiji 52.2008 mentions that the annual revenue from the market tax at the marketplace in the city Linzi 臨畄 (in modern Shandong, near the coast in the very east of the Han Empire) amounted to over 1,000 jin of gold.

41 I.e., 120 cash on each 2,000 or 4,000 cash of property value, respectively. Shiji 30.1430, trans. Watson 1993, 72. Cf. Lewis $(2015,287)$, who speaks of 10 percent for merchants and "just under 5 percent” for artisans. 
but it is generally assumed that they could not have endured in practice over a long period..$^{42}$

\section{II.3.4 Convertible Taxes}

Another clear example of the government's attempt at increasing the flexibility of its revenues can be seen in an originally purely in-kind tax on 'hay and straw per qing' (qing chugao 頃媰毫), which accompanied the land tax in grain and was used as fodder for state-owned horses and livestock, matting material, or in construction. With the expansion of the Qin empire into areas of more diverse agricultural or other productivity, the tax seems to have been handled more flexibly: either by partly commuting the tax into cash payments, or by accepting other in-kind payments (e.g., silkworm cocoons). ${ }^{43}$ Its further monetization is evident from a legal statute from the early Former Han period, which stipulates commutation of the tax to cash after the tax-collecting county agency's needs for hay and straw were satisfied. ${ }^{44}$ This testifies to a clear attempt by the state to make its fiscal revenues more flexible in an economic environment of increasing monetization. The beneficiaries of heightened flexibility, in this case, were the tax-collecting government agencies, not the taxpayers. ${ }^{45}$

\section{II.3.5 Revenues from State Participation in Market Exchange}

To changing and sometimes unknown extents, various central and local government agencies were involved in the production and sale of goods. ${ }^{46}$ With regard to certain state-produced goods such as lacquerware or textiles, it is largely unclear if they really played a role in the context of revenue maximization through market sales, or if state production of these were largely or even exclusively earmarked for direct consumption and redistribution. ${ }^{47}$ Better attested examples are those bran-

42 On the property or wealth taxes, see Yamada 1993, 220-238; von Glahn 2016, 114; Scheidel 2015, 154; Lewis 2015, 287-288.

43 There is evidence for this from the Qianling County archive (Liye), see Korolkov 2020, 110.

44 Barbieri-Low and Yates 2015, 696-697 (nos. 2 and 3 of the "Statutes on Agriculture"); Korolkov 2021b, 234-235.

45 This is further indicated by the second of these statutes (no. 3), which stipulates that whenever market prices of hay and straw exceeded the statutory price, the agencies were supposed to collect the amount of cash according to the current fair-market prices of hay and straw (which were geared to real market prices), rather than the statutory price (which would have been to the disadvantage of the agencies).

46 See also Leese-Messing, ch. 15, IV.2.3, this volume.

47 On this question, see also Leese-Messing, ch. 15, IV.2.2, this volume. 
ches of production in which the Han government held monopolies. With regard to monetary revenues for the state, this primarily concerns the salt and iron industries. $^{48}$

Salt and iron were considered natural resources belonging to the emperor. During the first decade of Han rule, entrepreneurs producing these products were taxed, probably in cash, at rates of one-sixth for salt production and one-fifth each for the production of iron itself and its subsequent processing to make iron implements. ${ }^{49}$ The revenue entered the emperor's privy treasury. Around 119-117 BCE, Emperor $\mathrm{Wu}$ introduced a state monopsony on salt and a monopoly on iron. ${ }^{50} \mathrm{Re}-$ portedly, revenues from both now entered the Ministry of Agriculture and were thus rededicated as public income that could be spent, for instance, on military endeavors. ${ }^{51}$ Yamada estimates that their revenues amounted to 3.8 billion out of close to 19 billion coins during Former Han times, which would have meant somewhat more than half of the land tax revenue in his calculation. ${ }^{52}$

As for the monopoly on iron, the state set up iron-manufacturing agencies that mined ore, and produced and sold iron implements. ${ }^{53}$ The agencies largely employed convict laborers. Iron was a widespread resource, so the monopoly may have been difficult to fully maintain, at least during times of waning government power. As for the monopsony on salt, production was left with private producers, who then had to sell the salt to state agents for resale. Since salt production was limited to few sites, it was likely easier to control, while promising permanent lucrativeness because of its indispensability. Unlike the monopoly on iron, it would also be employed by many later dynasties. ${ }^{54}$ Central state control over the salt and iron industries decreased considerably during the Later Han period. Administration of salt and iron offices were transferred from the central to local governments, and both monopolies seem to have been largely given up eventually. Nevertheless, state production of iron appears to have continued alongside private production, which remained subject to state control and taxation. ${ }^{55}$

48 That the importance of the monopoly on coinage did not primarily consist in its direct revenues, has already been pointed out above. Yet another monopoly, on liquor (see Hanshu 6.204), was only in force for a short period.

49 This is known from an excavated Former Han legal statute: Barbieri-Low and Yates 2015, 926929 (no. 12).

50 In the Sinological literature, both are most commonly termed 'monopolies.' But strictly speaking, the latter term only applies to the iron industry, which the state controlled as the only legal supplier. In the case of salt, the state controlled the market as the only legal purchaser, which corresponds to a market structure typical of a 'monopsony.'

51 Shiji 30.1429, trans. Watson 1993, 70-71; Wagner 2001, 11-12.

52 Von Glahn 2016, 117.

53 On the iron monopoly (and, alongside, also the salt monopsony), see Wagner 2001.

54 Lewis 2015, 288.

55 Wagner 2001, 16-17; 33-35. 


\section{II.4 Distribution of Extraction and Expenditure}

\section{II.4.1 Geographic Distribution}

In comparison to the Roman and Seleukid Empires, the early Chinese empires made a greater effort to standardize their fiscal system geographically, including regional tax burdens. During the first decades of Han rule, the central government certainly was a far cry from achieving this goal. This is especially true with regard to the eastern kingdoms, which initially were relatively independent of the central government with regard to the extraction of revenues from their domains, so that the central government largely relied on revenues from the areas in and around the metropolitan region surrounding the capital Chang'an. But the eastern kings' privileges, including those regarding taxation, gradually dissolved during the first century of Han rule, and the central government largely took control over the revenues from the eastern part of the empire as well. ${ }^{56}$

The fundamental practical elements of the fiscal system, including household registration and tax collection by state officials, were implemented throughout the whole empire, including frontier commanderies. This does not preclude that at least in some remote regions (such as in many mountainous areas, especially in the far south), large numbers of people likely remained out of reach for this system. Also, some frontier commanderies produced negligible incomes for the state and needed to be sustained by resources from the more central regions. But the systematic geographic imbalance of the Roman tax regime, which granted immunity from direct taxation to Italy as the central region of the empire and systematically laid the main tax burden on certain provinces, was alien to the idea and practice of taxation in early imperial China. ${ }^{57}$

With regard to the geographic redistribution of local government revenues, the early imperial fiscal regimes certainly transferred considerable amounts of its income to the center as well as to or beyond its frontiers. This is especially true with regard to Qin times and to phases of high military spending under Han rule, when the government was eager to centralize its revenues. ${ }^{58}$ Nevertheless, a big, general difference can be perceived with regard to fiscal distributive mechanisms between the Qin and the Han period. Whereas the Qin central government had been eager to have most of their tax revenues, especially monetary ones, transferred to the

56 On the changing status of the kingdoms, see also Leese-Messing, vol.1, ch. 4, 153.

57 On the geographic imbalances of the Roman tax system, see Weaverdyck and Fabian, ch. 8.A, II.2, this volume.

58 During Qin times, the central government was especially looking after the local governments' cash incomes, most of which were supposed to be transferred to higher administrative levels. See Korolkov 2021b, 219-221, 227. Early Han law still required cash incomes to be meticulously reported to higher administrative levels, but does not generally demand for the money to be transferred. Barbieri-Low and Yates 2015, 924-925 (no. 8 of the "Statutes on Finance," with n. 68). 
center, the Han fiscal system allowed for a much larger share of its tax revenues to be spent or kept locally. Estimates, which are partly based on excavated local administrative documents, suggest that by the first century BCE, the majority of inkind and nearly half of the in-coin tax revenues may have been retained on a local level. Meanwhile, the central government's budget increasingly relied on newly developed means of financing, such as the empire-wide establishment of salt and iron agencies. ${ }^{59}$ It has been suggested that the tendency toward local spending of tax revenues might also have resulted in an increasing provision of 'public goods' for local populations. ${ }^{60}$ More generally, and under the application of the basic suppositions of Hopkin's taxes and trade model, ${ }^{61}$ the trend toward the local spending of tax money and the relative homogeneity of fiscal extraction would render the role of the Han fiscal system as a promoter of long-distance trade less important than in the case of the Roman Empire. ${ }^{62}$

\section{II.4.2 'Equitable Delivery’ and the Fiscal Challenges of Transportation Costs}

The ideal of equalized taxation is also reflected in a contemporary term that appears in various excavated and transmitted texts in the context of taxation: junshu 均輸, literally meaning something like 'equitable delivery' or 'equalizing transportation.' This designation is chiefly associated with an accordingly termed policy initiated by Sang Hongyang 桑弘羊 (ca. 152-80 BCE) under Emperor Wu. It is briefly described in Sima Qian's chapter on economic policies and is further referred to in several passages of the Discourses on Salt and Iron (Yantie lun 鹽鐵論). Its interpretation as well as its relation to another policy termed 'balanced standard' (pingzhun 平准) has been a matter of controversy that started as early as the Han period itself and has continued until today. ${ }^{63}$ Whereas the scope, practical implementation, and impact of the concrete policy thus remain unclear, the central challenge that it confronted was clearly a fiscal one: "[W]hen taxes were transported from various parts of the empire, their value often did not equal the cost of transportation." 64 One factor that made this problem more pressing was territorial extension, because it went along with increased transport distances from the fringes of the empire to its center. Another was times of high government expenditure for wars. Both of these occurred during the time of Sang Hongyang's proposal. One central aspect of his approach

59 Von Glahn 2016, 113-120; Lianyungang shi bowuguan et al. 1997, 77-78; Korolkov 2020, 626.

60 Scheidel 2015, 179.

61 See von Reden and Speidel, vol. 1, ch. 17, 707-708.

62 For the latter, see Weaverdyck and Fabian, ch. 8.A, II.2.2; Weaverdyck, ch. 12.C, II.1, this volume.

63 For an overview of conflicting interpretations of the junshu policy throughout the ages, see C. Li 2019. On the 'balanced standard' (pingzhun), see further Leese-Messing, ch. 15, IV.2.3, this volume. 64 天下賦輸或不償其僦費. Shiji 30.1441, trans. Watson 1993, 82 (with modifications). 
therefore considered the choice of taxable goods from regions far from the capital. These goods needed to be suited for long-distance transport without delivery costs exceeding the value of the transported tax revenue itself. These were "local products which, when commanding a high price, would [ordinarily] be carted away and sold by traders." They were now to be "transported to the capital as taxes."65

Nevertheless, the basic problem of uneven transportation costs also existed during other times. The term junshu already occurs as the title of a statute collection in the Zhangjiashan legal corpus, which predated Sang Hongyang's policy by seventy years. But since no individual statute has been clearly identified as belonging to this title, we are left in the dark about what was meant by junshu in these early laws. ${ }^{66}$ The chapter entitled "Junshu" in the Former Han mathematical handbook Nine Chapters on the Mathematical Art (Jiuzhang suanshu 九章算術) reveals more. Whereas the concrete relationship to Sang's policies is again unclear, the mathematical tasks under this heading reveal the basic challenge and some concrete considerations that were likely at the bottom of all contexts in which the word junshu is found. At the center of many of the tasks lies the question of how transportation costs associated with certain goods, weights, values, and distances are to be calculated and apportioned 'fairly' or 'equally' across different counties and regions in the context of tax deliveries, probably with the dual goal of making the latter both efficient for the receiving and bearable to the paying and delivering parties. ${ }^{67}$

\section{II.4.3 Social Distribution}

As a legacy of the destruction of old aristocratic structures and the system of honorific titles introduced under Qin rule, which were at least theoretically built on meritocratic principles, notions of equality and uniformity lay at the core of the fiscal concept of the early empires, even though they never came to accord with social realities. ${ }^{68}$ Theoretically, all people had the same duties toward the state, unless they accumulated military or other merits that were rewarded with honorific titles and according tax exemptions. These principles, which had taken shape before and during the early years of the imperial period, had a lasting effect on Han discourses, in which social inequalities (including those in fiscal contexts) remained a common topic. This awareness, while not to be over-interpreted in its practical effects, may yet have put a cap on escalating tendencies of fiscal inequalities in both a geographic (see above) and a social sense.

65 各以其物貴時商賈所轉販者為賦. Shiji 30.1441, trans. Watson 1993, 82.

66 Even though the compilers of the inscribed slips designated two slips as belonging to these statutes, these slips are highly fragmentary, and their contents suggest that they may actually have belonged to other statute collections bearing different titles. Barbieri-Low and Yates 2015, 667-677. 67 Shen, Crossley, and Lun 1999, 307-348; C. Li 2019, 113-114.

68 Von Glahn 2020, 11; 2016, 104-105. 
The Han state spent a large share of its fiscal revenue on paying its own officials' salaries. In this regard, the Han system differed considerably from its Qin predecessor. During Qin times, low-level administrative tasks had largely been taken over by nonprofessionals, such as labor conscripts in monthly shifts, who were remunerated by grain rations, and who likely regarded these official duties as a burden rather than a privilege. The Han regime, by contrast, expanded its professionalized bureaucracy to these lower functionaries, who were now paid fixed salaries, and to whom officeholding evolved into an important marker of prestige. ${ }^{69}$ Reportedly, and not unconvincingly, the entire bureaucracy involved more than 130,000 officials in the year 5 BCE, with Later Han estimates even being somewhat higher (over 150,000). ${ }^{70}$ The sheer number of officials probably meant the overall expenditure for salaries was much higher than in the Roman Empire, despite the fact that Han salaries - even when adding imperial gifts and incomes from honorary fiefs - were much lower than their Roman equivalents. This is especially true with regard to high-level posts: the range of salaries between lowest and highest posts was much smaller in the Han than in the Roman bureaucracy. The redistribution of fiscal revenues by paying salaries to Han state functionaries was therefore a lesser factor contributing to social inequality than it was in the Roman system. ${ }^{71}$

State officials were paid fixed salaries as compensation for their administrative duties, an essential part of which concerned tax collection according to centrally prescribed rates and rules. Tax collection in early imperial China, therefore, worked on the basis of a so-called 'wage contract' system. ${ }^{72}$ This system involved a high level of monitoring costs and contributed to the state spending a large share of its fiscal revenue on paying its own officialdom. But the large-scale professionalization of the Han administration also contributed to a relatively stable level of state expenditure, at least during times of controllable military spending and in the absence of major natural disasters. This regularization therefore facilitated the state's maintenance of its fixed-rate, low-tax regime, which again was integral to the acceptance by the general populace and for the cooperation by local elites in particular. ${ }^{73}$

The Han fiscal system offered various elements and options that could be regarded as tolerable and even attractive by its subjects, and especially its local elites: First, tax rates in general (excluding phases like that of Emperor Wu's conquests) were tolerably low. Second, one option of benefitting from the system was to enter officialdom, get paid a fixed salary, and possibly climb up the bureaucratic and

69 Miyake 2013, 127-161; Korolkov 2021b, 238-239. On the identification of low functionaries with their jobs, see Selbitschka 2018b.

70 See Leese-Messing, vol. 1, ch. 4, 150.

71 For details of the Han-Roman comparisons, see Scheidel 2015, 165-174.

72 For a systematic approach to different varieties of contractual tax collection forms (share, rent, and wage) in history, see Coşgel and Miceli 2009.

73 Korolkov 2021b, 233. 
social ladder on this track. ${ }^{74}$ And third, in comparison to Qin times, the Han system left more room for local actors to evade taxation and to use the fiscal institutions for (illegal) enrichment.

Different kinds of sources indicate local functionaries and taxpayers fiddling with legal regulations in order to benefit from them by embezzlement and tax evasion. Historical texts record complaints by high state officials about local functionaries' submission of manipulated tax data and quote an emperor's lamentation that "the accounts submitted [by local officials] are nothing but unmeaning words, while what they are really engaged in is cheating and deceiving in order to avoid their dues” 上計簿, 具文而已, 務為欺謾, 以避其課. ${ }^{75}$ Excavated documents have shown more concretely how the manipulation may have worked. Some reports by officials on commandery level feature implausibly high numbers of elderly people, to whom the state granted certain tax exemptions on both individual and household levels, which may have allowed officials to embezzle parts of the local tax income. ${ }^{76}$ of course, misreports by the taxpayers themselves were also possible and certainly happened, but the reporting officials were in a better position to conduct this kind of fiscal fraud. Early Han legal statutes further show the state's concern over people illegally registering their own land under another person's name. A plausible scenario behind this concern would have been that people registered their fields under the name of a person holding a higher-order honorific rank who enjoyed legal exemption of the land tax on fields that he 'personally cultivated. ${ }^{, 77}$ One could also engage in trading activities beyond the official marketplaces, since many of these activities were difficult to control (and therefore, to tax). For members of local elites who were well connected to local functionaries (also by bribery), engaging in trading activities must therefore have been one of the most lucrative ways of making money in circumvention of the state's fiscal powers.

These examples offer an impression of the variety of loopholes exploited by both taxpayers and tax-collecting officials. Both transmitted and excavated evidence shows flourishing networks between members of local elites and functionaries, the majority of whom were appointed locally, and further indicates collabora-

74 Lewis $(2015,297-298)$ suggests that in the long run, the system of distributing of wealth into the hands of officials was inherently doomed to failure in the sense that "the state expended much of its income on salaries, which were then turned into land purchases," and these purchases again "reduced the number of free peasants and, consequently, the state's tax income." As a result, the Han state "gradually starved of the wealth that [it] needed to survive."

75 Hanshu 8.273 (my translation), being a quote from a decree by Emperor Xuan (r. 74-49 BCE) issued in 49 BCE.

76 Hsing 2014, 182-184; Korolkov 2021b, 241. For further indications of misreporting, see D. Gao 1998.

77 Barbieri-Low and Yates 2015, 796-797 (no. 14 of the "Statutes on Households,” with n. 87), 792793 (no. 7 of the "Statutes on Households," with no. 60). 
tion. ${ }^{78}$ One of the goals of this kind of networking would plausibly have been to execute common strategies for tax evasion.

To a certain extent, the central Han government tolerated this legal and illegal capitalization on the fiscal system by state functionaries and local elites. Leaving exceptional phases apart, this relative (though definitely not boundless) lenience distinguished the Han fiscal system from its Qin predecessor and was the basis of what has been described as an 'imperial consensus' between the central government and local elites, which likely played an important role in the Han Empire's longevity. ${ }^{79}$ But the ability of the state to maintain low taxes and tolerate loopholes for members of local elites also rested on the foundation that tax compliance in general appears to have been relatively high after all. ${ }^{80}$ During times without extraordinary expenditures (e.g., overflowing military costs), the central government could sustain itself and its whole state apparatus on the basis of relatively regularized incomes and costs.

\section{Monetization}

\section{III.1 Introduction}

The early imperial period was the time when monetization became a ubiquitous phenomenon in all spheres of society. The use of copper coins spread massively, both in terms of the overall scale of money supply, and in geographic and social terms. Cash became the primary unit of account, payment, and exchange in both private and state-related transactions. Coins made their way from the central regions of the empire to its frontiers, including formerly nonmonetized regions. They penetrated all layers of society, from the highest elites to ordinary peasants, and played a central role in all kinds of economic interactions. These developments were concomitant with a high level of standardization, which was aided by a state monopoly on coin casting. The vital role of imperial state institutions - including its fiscal and legal systems - in the spread of coined money is further indicated by the return to the use of commodities rather than coin in economic transactions once the power of government institutions faded, and especially after the Later Han Empire broke apart.

Scheidel suggests a rough estimate ranging between 30 and 70 billion cash as the aggregate value of all gold, silver, and bronze money (including bullion, see below) at the end of the Former Han period, which would be equivalent to 6 to 28 billion liters of grain. These estimates are substantially lower than the estimates

78 Korolkov 2012, 311-325.

79 Korolkov 2021b, 204, 239, 243.

80 Scheidel 2015, 155. 
that have been suggested for the Roman Empire at its peak monetization level, i.e., 10-20 billion sesterces or a corresponding 22 to 90 billion liters of grain. Given that the estimates for state revenues are similar for both empires, ${ }^{81}$ the assumed discrepancy in money stocks suggests a lower monetization level in the Han Empire, which by comparison would have left fewer coins available for commercial exchange and hoarding. ${ }^{82}$ Nevertheless, with ordinary farmers and even convicts regularly participating in monetary transactions, coin use in the Han Empire seems to have penetrated deeply into even the lowest echelons of society. ${ }^{83}$

\section{III.2 Coin Money}

\section{III.2.1 Characteristic Features of Early Imperial Coins}

Unlike the Roman and Hellenistic worlds, coins made of precious metal (i.e., gold and silver) were a marginal phenomenon in early imperial China. Apart from the relatively gold-rich, southern state of $\mathrm{Chu}$, whose currency system had also included square gold plates, the Warring States period had already been dominated by base metal currencies, mostly in the form of miniaturized bronze spades and knives. ${ }^{84}$ Metal supply constraints probably played a key role in this phenomenon. But some other factors have also been suggested, such as the widespread use of unpaid conscript soldiers instead of mercenaries during the pre-imperial and the beginning of the imperial period, in combination with the fact that even after imperial expansion, the early empires were "never drawn into an environment dominated by precious-metal coinage." ${ }^{85}$ In the long run, familiarity with bronze coins may simply have made any deviation from this internalized norm difficult to be accepted as proper money. ${ }^{86}$

81 With regard to the Han empire in the late first century BCE and the Roman Empire in the midsecond century CE.

82 Scheidel 2009, 199-202.

83 Von Glahn 2016, 120. For evidence on Qin convicts buying foodstuffs for cash, see Korolkov 2020, 593-594. Even though farmers' degree of participation in the monetary economy certainly increased during the early imperial period, there is also some evidence for pre-imperial farmers using money. See K. Peng 2000, 173-175.

84 On pre-imperial currencies, see X. Peng 1994, 1:23-75; Thierry 2017, 21-53; 1997. On the relation between monetization and commercial development during the pre-imperial period, see K. Peng 2000. For parallels between China and Western Eurasia in the use of metal-object currency (including those in the form of tools), see Bresson 2021.

85 Scheidel $(2008$, 279) further remarks that the Roman Republic, which also practiced mass conscription, did not feel the need to change from bronze nominations to precious-metal coinage before it entered substantial conflicts with Greek and Hellenized competitors, who were using silver coinage.

86 For a discussion of potential reasons behind the predomination of bronze coins in ancient China, see Scheidel 2008, 276-284. The fact that even as late as the Ming period (1368-1644 CE), when 
Round coins - usually featuring a square hole in the middle - first appeared in the fourth century BCE in the states of the North China Plain. They became universal during the early imperial period in the form of the Qin banliang 半两 ('half-ounce') ${ }^{87}$ and the Han wuzhu 五銖 ('five-zhu') ${ }^{88}$ bronze coins, both of which basically circulated as single-denomination currencies. Two other characteristics of early imperial (but also later) Chinese coins are that they were not minted but cast, and that they almost exclusively have scriptural elements indicating their (nominal) weight rather than featuring any iconographic design. ${ }^{89}$

\section{III.2.2 The Role of Imperial Expansion in Monetization Processes}

The impact of imperial expansion on processes of monetization was manifold and took place in different directions. During the Warring States period, the level of monetization in the form of coins had been considerably lower in the state of Qin than in the states to its east and southeast. The integration of the eastern states by the Qin resulted in a more thorough monetization of the imperial center. In this case, one could thus say that imperial expansion led to an inward-directed monetization process. Integrating the more monetized eastern economies into its fiscal system, which had itself been dominated by in-kind levies and expenditures (including, for instance, salaries), turned out to be one of the most difficult challenges that the Qin state faced after its imperial expansion. Initial steps toward a monetization of the labor market and of the fiscal system were already made in Qin both before and after the unification in 221 BCE.

As for outward-directed monetization processes, both Qin and Han imperial expansion into previously non- or hardly monetized regions at the outer rims of the empire appears to have been the decisive factor for these regions' use of coined money in the first place. Typical and well-attested examples are the Qin southward expansion and the northwestern expansion into the Hexi corridor and the Tarim Basin under Han rule. Both appear to have witnessed no or hardly any use of coined money before their conquest, yet both eventually developed into thoroughly monetized areas. ${ }^{90}$ Furthermore, government institutions themselves obviously played an

silver was actually available in large quantities, silver coinage was still rejected, suggests that the habitual factor may have played a considerable role.

87 Indicating a target weight of approximately $7.8 \mathrm{~g}$.

88 Indicating a target weight of approximately $3.3 \mathrm{~g}$.

89 There were rare exceptions, such as in the case of a short-lived attempt under Emperor $\mathrm{Wu}$ to introduce three 'white metal' (baijin 白金), highly overvalued denominations featuring a dragon, horse, and tortoise design, respectively. Shiji 30.1427, trans. Watson 1993, 69. See further Thierry 2017, 103-105.

90 On the Qianling (Liye) region, see Korolkov 2020, 605-610. On the northwest, see H. Wang 2004. On the role of the military and imperial expansion in monetization processes, see also LeeseMessing, ch. 6, IX, this volume. 
active role in pumping coined money into these local economies. This happened, among other ways, through the local government agencies' purchases from local residents, or through the issuing of monetary rewards, for instance to individuals who had denounced or arrested criminals. In comparison to the Roman case, ordinary Qin and Han soldiers, many of whom were conscripts receiving rations rather than money payments, played a lesser role in frontier monetization processes. During Han times, however, cash salaries for military officers and, particularly, administrative officials on all levels accelerated local monetization processes, both in central and frontier commanderies. ${ }^{91}$

\section{III.2.3 State Control over Coin Production}

State control over coin production appears to have existed at least during some of the Warring States polities (including Qin and Qi 齊) during the third century BCE. ${ }^{92}$ After the Qin unification, local currencies continued to circulate despite the Qin's attempts to make their own banliang coins the only recognized currency. ${ }^{93}$ And when the Han dynasty first established its rule, limited government power did not permit a centralist approach to coinage. The founding emperor of Han, Gaozu 高祖 (Liu Bang 劉邦, r. 202-195 BCE), officially legalized private casting of banliang coins (which had been introduced by the Qin earlier) under the condition that these adhered to the imperial standard in alloy, weight, form, and design. As a result, the following decades up to the 110s BCE saw the imperial palace, kings, and private entrepreneurs casting banliang coins side by side, which led to a sharp increase of the circulating volume of coins. Along with the state's decreasing reliance on military and labor conscripts, and its increasing demand for more flexible revenues, this provoked further monetization of the fiscal system. In-cash taxation increased considerably, and - as a huge difference to Qin times - state officials on all levels were now partly paid in coin as well. These developments in the fiscal system, again, increased the demand for coined money in the private economy. ${ }^{94}$ Both state and private actors therefore appear to have been involved in a 'snowball effect' process that led to a substantial increase in the level of monetization during the first century of the Former Han period.

The same period also witnessed a notable decline in actual coin weights and corresponding price inflation, accompanied by a gradual official depreciation of coinage, including the introduction of a so-called 'four-zhu banliang' standard. Con-

91 During Qin times, officials had still mainly been paid in kind. Korolkov 2020, 605-609.

92 Scheidel 2009, 141.

93 Kakinuma 2015, 60-62.

94 The developments of the early Former Han period are sketched in Shiji 30.1417-1419, trans. Watson 1993, 61-63. 
temporary critics also observed considerable regional variation of coin weights, so that "in some places the coins used were so light that to every one hundred of them must be added a certain number” 或用錢輕, 百加若干 (and the other way around)..$^{95}$ Furthermore, the political danger involved in private coin casting was shown to the Han central government quite plainly by the seditious Rebellion of the Seven Kingdoms in 154 BCE. It had been initiated by a king whose power had been based on the fortune he had made from mining copper and casting coins. This experience eventually resulted in a prohibition of private coin casting. ${ }^{96}$

The Han government extended central state control over coinage when Emperor Wu's military campaigns afforded massive new expenses. After some experiments with further depreciation, the introduction of highly overvalued token issues, and the introduction of an elevated wuzhu standard resulting in massive production of underweight versions, Emperor $\mathrm{Wu}$ eventually prohibited any coin casting apart from three central casting facilities and ordered the demonetization of all earlier coins. These measures of further centralization were accompanied by technological advances allowing for massively produced, highly uniform coins with raised and perfectly smooth rims, which made the production of credible counterfeit coins costly. ${ }^{97}$ Another important factor for the latter was that the nominal value of the coins did not overly exceed their intrinsic metal value. This package of polices eventually resulted in relatively stable standards in alloy and weight, an output of 28 billion pieces produced during the following century, and an apparently much lower level of counterfeiting. ${ }^{98}$

\section{III.3 Other Forms of Money}

\section{III.3.1 Bullion}

The use of precious metals as money was largely limited to the use of bullion, particularly in the form of normed gold ingots known, for instance, as 'horse-hoof gold'

95 Hanshu 24B.1154, trans. Swann 1950, 235 (with minor modifications); Scheidel 2009, 145.

96 Shiji 30.1419, trans. Watson 1993, 62.

97 Shiji 30.14251435, trans. Watson 1993, 68-77.

98 If estimates with regard to the (highly similar) coins of the Tang period are any indication, one may speculate that Han wuzhu coins were priced at approximately twice their intrinsic value. Thierry 2003, 115; Scheidel 2009, 150, 193-194; Hanshu 24B.1177. Scheidel suggests that under the given circumstances, "the threshold for widespread demonetization (and counterfeiting) would not have been reached until coins were assigned a face value that amounted to several times their intrinsic worth" $(2010,99)$. The question whether early imperial coins are to be seen as fiduciary or fiat money whose intrinsic value was of little importance has been a matter of controversy. Whereas Thierry (e.g., 1993; 2001) in particular stresses the fiduciary aspect of ancient Chinese coins, Scheidel $(2010,95,101)$ has argued that not unlike the Roman case, Chinese money was characterized by "a strong nexus between the quantity and quality of coin on the one hand and its valuation on 
(matijin 馬蹄金) or 'gold biscuits' (jinbing 金餅). During Han times, gold ingots were weighed (but not regularly cast) in units of 1 jin (ca. $244 \mathrm{~g}$ ). Archaeological finds attest to their high fineness, which most commonly ranges between 97 and 99 percent purity. ${ }^{99}$ Generally speaking, gold appears to have played a secondary role in relation to the bronze currency, but it was essential as a unit and store of value, in certain high-value transactions, and, particularly, in imperial gift-giving. Its importance decreased during the Later Han period, when its functions were partly taken over by silver and textiles, with the latter evolving into the most important form of imperial gifts. ${ }^{100}$ Gold, in the unit of liang, is mentioned frequently with regard to fines in Former Han legal statutes, but one statute makes clear that these fines in gold could be paid in cash. ${ }^{101}$

Thanks to its relatively stable and reliable bronze coinage, the 'flight into gold' that characterized the late Roman system as a function of frequent debasements and devaluations (and therefore, unreliability) of base-metal coins appears to have played a lesser role in the Han Empire. ${ }^{102}$ Some transmitted sources mention centrally fixed exchange rates between cash coins and gold or silver, but it remains unclear to what extent and for how long these exchange rates were actually implemented. ${ }^{103}$ The Han legal statute mentioned above indicates that a 'fair-market price' (ping jia 平價) for gold was to be determined annually on commandery level, indicating that official rates changed from year to year and from commandery to commandery. At least at the time the statute was written during the early Former Han period, this 'fair-market price' appears to have had direct implications only for official purposes (i.e., transactions involving government offices, such as payment of fees), whereas actual market exchange rates were acknowledged to be fluctuating. 104

\section{III.3.2 Textiles and Grain}

Unlike some post-Han regimes, including most famously the Tang 唐 Empire (618$907 \mathrm{CE}$ ), textiles were not a regular form of either tax revenue or officials' payment

the other," and that the "market value of coin was primarily a function if its intrinsic value." Nominalist conceptions and ideals of coinage, as well as according legal regulations, definitely existed, but the evidence in ancient Chinese sources that speak in favor of a practical dependence of the coin market value from its intrinsic value is overwhelming.

99 X. Zhang 1985; Y. Wang 2005, 273.

100 H. Wang 2004, 13-14; Nishijima 1986, 589-590; Scheidel 2010, 94; 2009, 159-169; X. Peng 1994, 1:134-147.

101 Barbieri-Low and Yates 2015, 922-923 (no. 7 of the "Statutes on Finance").

102 Scheidel 2009, 185.

103 For primary evidence mentioning fixed rates, see, for instance, Hanshu 24B.1178, trans. Swann 1950, 327. See further Nishijima 1986, 589-590; Lau and Lüdke 2012, 180-181 (n. 893), 195 (n. 949).

104 For more on 'fair-market prices,' see Leese-Messing, ch. 15, IV.2.3, this volume. 
during Han times. ${ }^{105}$ During Qin times, the bolt of cloth was obviously a unit of account, but its relevance as a unit of exchange is contested among scholars and certainly further decreased under Han rule. ${ }^{106}$ Both Qin and Han state institutions did, however, have an ongoing high demand for textiles for the clothing for officials, soldiers, and laborers, and indirectly extracted textiles from its people through state workshops using conscript labor. But excavated documents from Qianling (Liye) also suggest that already in Qin times, textiles were the main good that local governments purchased from private markets. ${ }^{107}$

Excavated administrative documents from the northwestern Han frontier occasionally mention 'salary-silk' (lubo 祿帛) and 'salary-cloth' (lubu 祿布) in addition to the most common in-coin payment of officials. ${ }^{108}$ Han imperial law prescribed normed cloth widths for the sale of certain textiles, including silk, at marketplaces. ${ }^{109}$ While this might point toward a money-like function of textiles, it does not necessarily have to be interpreted this way. While also a question of definition, it is at least safe to say that the monetary use of textiles in both official and private transactions was much less important during Han times in comparison to the pre- and post-Han period. ${ }^{110}$

Grain had been used as the primary form of officials' salaries during Qin and earlier times. The Han continued to express the ranks of officials in bushels of grain, but actual salaries were paid out at least partly, if not largely, in coin. But other than civilian officials and officers, conscripted soldiers may still have been largely compensated in grain. ${ }^{111}$ Even though not much is known about its use in private transactions, monetary use of grain seems to have diminished considerably during the Han period, after which it eventually regained importance.

On a more general note, the use of textiles and grain as money increased during times of governmental instability, such as the later phase of Wang Mang's 王莽

105 For Qin times, see, e.g., Hulsewé 1985b, 227-229. For Tang times, see Twitchett 1970, 66-83; H. Wang 2013.

106 For a short summary of the debate and bibliographic references for different standpoints, see von Glahn 2016, 99, esp. n. 55.

107 Korolkov 2020, 584-590. In the context of the 'equable delivery' system, the 'learned scholars' of the Yantie lun also mention occasions during which local government institutions "ordered the people to make woven goods” 令民作布絮, which they were then forced to "sell at a cheap price in order to satisfy demands from above” 賤賣貨物, 以便上求. Yantie lun jiaozhu 1.4, trans. Gale 1967, $10-11$.

108 For the use of textiles in salaries at the Han frontier at Juyan, H. Wang 2007; 2004, 48, 51; Loewe 1967, 1:96; 2:100-103 (MD 12, no. 5).

109 Barbieri-Low and Yates 2015, 722-723 (no. 1 of the "Statutes on [Passes and] Markets”).

110 References to textiles as a means of payment to the state do occur in the Qin legal statutes from the Shuihudi site, but are absent in the legal texts from the Former Han period excavated at Zhangjiashan. See von Glahn 2016, 99-100. In any case, it is impossible to tell how much monetary use of textiles contributed to the overall money supply. Scheidel 2009, 202.

111 H. Wang 2004, 15, 49, 50-51; Scheidel 2009, 183; Loewe 1967, 1:93-94; 2:69-71. 
(r. 9-23 CE) interregnum and especially after the fall of the Han dynasty when coined money retreated along with political stability and central government power, and textiles along with grain became the primary media of exchange. ${ }^{112}$ This change was also mirrored in the post-Han fiscal system, in which the in-coin poll tax came to be replaced by a household tax paid in cloth. ${ }^{113}$ This suggests that the efficiency and stability of state control appear to have been crucial in the functioning of the early imperial currency system.

\section{III.4 Credit}

\section{III.4.1 Interpersonal Credit}

The historical records of the Han period frequently mention informal, private moneylending, including large-scale transactions involving millions of cash. Debtors ranged from common peasants to people of high social standing, including officials and imperial relatives. ${ }^{114}$ The texts mention a large variety of interest rates and indicate that the state made attempts at restricting private usury by prescribing maximal rates, the limits of which are, however, unknown. ${ }^{115}$ Securing loans by pledges ( $z h i$ 質, in the form of land, other properties, and people) also appears to have been common. Complaints about rich people ruining peasants and appropriating their land by moneylending, probably on the basis of mortgage credits, occur frequently in historical accounts of the Han period. Whereas both legal regulations and social criticism were aimed at setting certain limits to private moneylending, both of them mostly acknowledged and sanctioned private lending practices as a perfectly normal and legitimate socioeconomic practice. That local government agencies were involved in the ratification of credit contracts, and that they could be called for intervention in the case of interpersonal conflicts arising out of credit agreements, indeed suggests that state institutions and the judicial system in particular must be considered important supporters of private lending activities, as long as they occurred within certain bounds. ${ }^{116}$

112 X. Peng 1994, 1:208-213; H. Wang 2013; 2004, 14.

113 Lewis 2015, 298.

114 X. Peng 1994, 1:183.

115 The according text passages simply say that certain people practiced moneylending using rates that exceeded the legal regulations. X. Peng 1994, 1:183; Y. Li 2018, 81-82. Examples collected from transmitted sources suggest 20 percent to have been a common annual rate, excess of which may have been regarded as usury (Swann 1950, 392, 432, n. 103). For evidence for different time limits for repayments and different frequencies of interest collection, see Shi 2018.

116 Y. Li 2018, 81-84. See also sec. IV.3 below. As for concrete examples of limiting regulations, an early Han legal statute prohibits state officials at or above the 600-shi salary trade and those personally serving the emperor from engaging in moneylending at interest, and another prohibits creditors from forcing a pledge. Barbieri-Low and Yates 2015, 614-615 (nos. 3 and 4 of the "Statutes on 
Excavated private credit contracts typically display modest loan amounts and are of strongly local character, with both parties frequently bearing the same surname, potentially indicating kinship relations. Some of the contracts further mention the cause for the debtor's demand for money, such as outstanding tax payments. ${ }^{117}$ What is less well known is how and to what extent private money loans were used beyond situations that demanded counterbalancing of temporary shortages, for instance as investment credits for merchants and other entrepreneurs. What seems clearer is that in contrast to later periods such as the Tang era, private moneylending did not reach a high level of institutionalization nor professionalization during Han times. ${ }^{118}$

\section{III.4.2 State Credit}

Transmitted and excavated sources show that government institutions were engaging in various forms of lending activities. First and foremost, stored state-owned goods such as grain seeds, agricultural tools, carts, and draft animals could be lent to commoners. These opportunities certainly had the potential to facilitate the work of small-scale independent peasants - and possibly of alleviating their disadvantages vis-à-vis richer landowners' investment possibilities to a certain degree. After all, the fiscal system relied on the independent farmers' ability to pay their taxes. Another important aspect of these lending activities concerns their blending with local government institutions' task of managing labor. As mentioned, this contributed to the development of a mental and institutional framework of labor as a quantifiable commodity. ${ }^{119}$

At least during Qin and early Former Han times, the lending of money does not seem to have been typically involved in the agency's tasks. What legal regulations from that period do indicate is a strong interest in prohibiting local officials from using money (and other valuables, such as gold, silk, and horses, but also grain) under their custody for private lending activities, a behavior deemed a serious crime that involved the same punishment as robbery. ${ }^{120}$ One may wonder if such regulations had been necessary at all if a legal option of moneylending by local government institutions existed. In any case, the statutes dealing with legal lending activities of local government offices never explicitly refer to cash, but either rather generally to “loans” ( $j i a$ 叚=假) or “items” ( $w u$ 物) to be returned, ${ }^{121}$ or to concrete

Miscellaneous Matters”). On regulations concerning moneylending, see further Z. Wang 2002; Q. Xie 2007.

117 Y. Li 2018, 79-80.

118 X. Peng 1994, 1:185. For Tang times, see X. Peng 1994, 1:329-331; Adshead 2004, 68-100.

119 See sec. I.2.1 above, and Leese-Messing, ch. 6, IV, this volume.

120 Barbieri-Low and Yates 2015, 270-271 (no. 16 of the "Statutes on Currency").

121 For instance, Barbieri-Low and Yates 2015, 472-473 (no. 17 of the "Statutes on Currency"). 
commodities like the ones mentioned above. ${ }^{122}$ In what is probably to be seen as an exceptional and short-lived attempt at curbing the power of private moneylenders over the poor peasant population, Wang Mang introduced a comprehensive system of governmental credits (shedai 賖貸) under the control of market officials and backed by the fiscal revenues from commercial taxes on traders and craft producers. It was supposed to involve interest-free interim loans for worship and funerary expenses $^{123}$ as well as loans on interest for investments into people's "means of livelihood" (chanye 產業). ${ }^{124}$ In both cases, the historical account speaks of destitute people as the envisaged borrowers, which speaks in favor of relatively small-scale bridging credits rather than larger business investment credits. ${ }^{125}$

\section{III.5 Conclusion: Economic Impacts}

Monetization doubtlessly reached unprecedented levels during Han times with regard to the overall quantity of circulating coins as well as with regard to geographic and social distribution. The state monopoly on coinage helped to establish a relatively stable and highly standardized currency used across the vast space of the Han Empire. Several aspects of early imperial monetization processes can, however, be considered as potentially confining factors. For instance, the single-denomination system resting upon base-metal coinage must have been considerably less flexible than the multi-denomination currencies that characterized the Mediterranean world during the same period, especially when it comes to large-scale economic transactions. The relative underdevelopment of the credit system, as least as it is suggested by the evidence, points in the same direction. Taken together, such factors must ultimately have limited the potential of monetization as a minimizer of transaction costs, especially with regard to large-scale and long-distance private trading activities.

122 For the lending of tools, for instance, see Shuihudi Qin mu zhujian zhengli xiaozu 1990, 45 (slips no. 104-107); Hulsewé 1985a, 60 (A57). In the same manner, references to people's 'debts' (ze/zhai 責) to local government agencies or according 'debt tallies' (zequan/zhaiquan責券), are nowhere said to have resulted from moneylending. To give just one example, one excavated document from Liye uses the latter term in the context of the 'debt' that one person owed to the local government agency by not having returned a borrowed state-owned boat on time. W. Chen 2012, 72-76 (tablet 8-135).

123 These interest-free loans were limited to short periods of ten days and three months, respectively.

124 Hanshu 24B.1181, trans. Swann 1950, 342 (with modifications).

125 The historical records also mention other occasions when the state granted credits to sick widows and widowers as well as other people without the means of earning their livelihoods. They further mention instances of the state cutting outstanding debts that people owed to government institutions. X. Peng 1994, 1:183. 


\section{Law}

\section{IV.1 Introduction}

The extensive archaeological finds of Qin and Han legal texts during the last decades, including collections of codified statutes and model legal cases, have been a revelation with regard to the overall importance and the concrete contents of early imperial law. ${ }^{126}$ The new evidence has also shed much light on the economic function of law. Many statutes concern aspects of the state economy and transactions between government agencies and the population, but some also regulate private property and trade. Massive finds of administrative documents have furthermore confirmed the practical implementation of imperial law on the local level. They also suggest that local or regional legal traditions that had existed in the pre-imperial period were superseded or incorporated into the system that now operated on an imperial scale. Some economically relevant aspects of early imperial law are being addressed in other sections and chapters in this volume. ${ }^{127}$ The following subsections, without any claim to be exhaustive, focus on two broader aspects of the legal system that are both well documented in the available evidence and can be regarded as fundamental in setting the course of economic activity in early imperial China: authentication of property rights and use of contracts.

\section{IV.2 Property Rights}

The protection of property rights by official notarization and enforcement is generally acknowledged as one of the major reducers of uncertainties and transaction costs for economic activities in both modern and ancient societies. The aforementioned excavated legal texts have shed new light on how the early imperial state was actively involved in this process.

Qin and Han legal statutes comprehensively regulated property right transfers in the context of inheritance and sales of various kinds of property. They further treated contexts of property loss and damage reimbursement, and debt relations between government agencies and individuals as well as among private individuals. ${ }^{128}$ These regulations and records were essential for the state's control over fiscal

126 For translations of major finds of Qin and Han legal texts, see Hulsewé 1985a; Barbieri-Low and Yates 2015; Lau and Staack 2016; Lau and Lüdke 2012. On the judicial system in general, see also Leese-Messing, vol. 1, ch. 4, IV.3 (164-172).

127 For market(place) regulations, see Leese-Messing, ch. 15, IV.2, this volume. For further aspects discussed elsewhere, see also the following footnote.

128 For inheritance regulations, see Leese-Messing, ch. 6, VI, this volume. For credit regulations, see sec. III.4 above. For regulations on property damage reimbursement, see, for instance, Hou 2014. 
matters, but most likely were also an important reassurance of property rights for the people themselves. The same is true for legal statutes that regulated property transfers by sale. From the early Former Han period onward, these legally acknowledged transfers also included sales of agricultural land. Resulting changes of ownership were to be entered into the registers by local government offices within one day of the transaction. ${ }^{129}$ By this legal sanctioning, the Han state ultimately promoted private sale of land. Such regulations marked the transition to a private land market from the former system of state-managed redistribution, in which people's entitlement to land holding had been centrally based on their honorary ranks. ${ }^{130}$ Crimes involving illegal appropriation of other people's or the state's property, i.e., 'robbery' (dao 盜), were also treated extensively by both Qin and Han legal statutes. ${ }^{131}$ Furthermore, making profit by cheating others in private business transactions was treated as a parallel to the crime of 'robbery' by Han law, and was to be punished accordingly. ${ }^{132}$

Local administrative staff included both people that pursued criminal investigations and 'police officers' whose task it was to chase criminals such as robbers. Given the authorities' limited means of effectively policing large areas and populations, a legally institutionalized "system of unofficial law enforcement" furthermore encouraged cooperation among the populace for these tasks. ${ }^{133}$ On the basis of precise legal regulations, people who denounced, arrested, or killed criminals were awarded preassigned rewards in the form of monetary payments and entitlements of honorary ranks. The role of the state's judicial system in the persecution of crimes against property therefore went beyond that of mediation, which underlines its active role in the protection of personal property rights.

Other imperial regulations may seem a mere impediment of regional and interregional trade at first sight. One example, known from a Qin statute in the Yuelu Academy collection, is the imposition of fees for the issue of 'passports' that people needed to carry if they wanted to sell certain movable goods such as cattle, horses, or slaves across the borders of a county. ${ }^{134}$ It must not be neglected, however, that

129 For Qin times, there is hardly any evidence for either sales of land or legal acknowledgment of land to be part of one's individual property at all (Korolkov 2020, 561). For the early Han legal statute prescribing local officials to immediately enter changes of land ownership into the official registers, see Barbieri-Low and Yates 2015, 797 (no. 13 of the "Statutes on Households").

130 On these developments, see M. Gao 2003; Z. Yang 2003; J. Zhang 2007. Reportedly, this gradual transition started to be officially sanctioned by a Qin in reform in 216 BCE, which legalized the recognition of private land tenure on the basis of self-declaration. See Shiji 6.251, commentary no. 1, referencing Xu Guang 徐廣 (352-425 CE).

131 For according Qin statutes, see Hulsewé 1988. For the Han “Statutes on Robbery,” see BarbieriLow and Yates 2015, 456-491.

132 Barbieri-Low and Yates 2015, 722-723 (no. 2 of the “Statutes on [Markets and] Passes”).

133 Korolkov 2016.

134 S. Chen 2015, 133-134 (nos. 198-201). 
trading valuable goods over distances was always associated with higher risks. These are likely to have been mitigated by a reliable verification of ownership that the state's system of well-interconnected local offices could provide. In the long run, such regulations might therefore also have had some promoting (rather than just impeding) effects on the development of interregional markets. ${ }^{135}$

\section{IV.3 Contracts and their Enforcement}

The degree of reliability of contracts, however they were enforced, is another important aspect of transaction cost reduction in various kinds of economic practices such as selling or lending. Contracts of various kinds, covering the fields of property law, law of obligations, family law, and employment law, were a common phenomenon in both the Qin and Han periods. They are mentioned in transmitted historical texts and excavated legal statutes, and have themselves been excavated from tombs and other archaeological sites. Whereas the term yue 約 ('agreement') could be used for any kind of agreement, including oral ones, the use of the technical terms quan 券 ('tally', 'contract') or quanshu 券書 ('contract document') was confined to written agreements, including contracts. ${ }^{136}$ Private actors used contracts either in transactions with state institutions (e.g., in sale or lending transactions) or among themselves. They were used in a variety of contexts, such as sale of land, purchase on credit, hire, or group agreements for common business undertakings. ${ }^{137}$ Wills, too, were documented in the form of 'tallies' or 'contracts' (quan). ${ }^{138}$ Contract documents were most typically made out of wood and took the form of two- or three-part tallies, with one part each given to the two parties of transaction, and the third (if applicable) to a particular government office, with all parts carrying the same text. ${ }^{139}$ Both evidence from excavated legal texts and excavated contracts themselves now suggest that apart from the written characters, some contracts also carried their essential information (such as on the sold product, its amount, and its price) in the form of perforations on their edges, which are likely to have primarily served as a measure against manipulation of the contract text. ${ }^{140}$

Contracts of the Han period feature a considerable degree of uniformity across space and time with regard to their content, structure, and style. Sale contracts, for

135 Korolkov 2020, 116, 567-568.

136 Written receipts (e.g., for the payment of a fee) also fell under the category of quan.

137 Hulsewé 1978; Scogin 1990.

138 On wills, see, e.g., Hinsch 1998.

139 On the multipart tallies, see, for instance, Hsing 2017; Barbieri-Low and Yates 2015, 425-426 (n. 70), 453 (n. 208); Ma, vol. 1, ch. 12.B, 548, 550-551, with further references.

140 On the perforations, see Momiyama 1998 and the legal case from the Book of Submitted Doubtful Cases (Zouyan shu 奏讞書) in Barbieri-Low and Yates 2015, 1394-1416 (with n. 16 on 1409-1410); Ma, vol. 1, ch. 12.B, 550-551. 
instance, typically mention the date of transaction, the buyer and seller (by name and with places of origin), the object of sale, the price (in cash), a declaration of payment, witnesses, and a phrase saying that all present had drunk wine that the two parties had bought together. ${ }^{141}$ Some contracts (such as in the case of land that had not been seen by the buyer), also include a guarantee clause (e.g., "If the fields are insufficient, the acreage will be figured again and money refunded"). ${ }^{142}$

Different kinds of evidence show quite clearly that the enforcement of private contracts was not just left to informal, customary practice, but was an important practical function of the Han state's legal system. Transmitted texts from the Han period occasionally refer to the use of contracts to decide lawsuits between individuals. The Later Han scholar Wang Fu 王符 (ca. 82-167 CE) complained about an over-abundance of lawsuits on disputes evolving from private agreements regarding moneylending or betrothals, which involved everyone from commoners to the wealthy and nobles. ${ }^{143}$ Han legal texts also include several statutes that mention contracts. For instance, tampering with contracts is listed as a crime, and one statute prescribes the use of tripartite tallies for will 'contracts,' immediate report to the county court, and that the local officials "carry out matters according to the contract document” 以券書從事 in the case of dispute. ${ }^{144}$ In the case of wills, just like in the transfer of valuable property by sale, state officials were thus not only meant to mediate the issue on the basis of the contract, but also to ultimately 'carry it out': They entered the new owners and (potentially) householders into the county's official registers, which fixed the new distribution of property rights.

Which role state institutions played in the ultimate enforcement (if necessary, by coercion) of other agreements such as credit or employment contracts is more difficult to say. In the Roman case, this part of enforcement was left to private order, which worked without state coercion, but rather on the use of witnesses bound by "mechanisms of reputation and social control." 145 When handling legal cases, Qin and Han government agencies played an active role at least in mediation, as is demonstrated by an excavated official case report from Qin times involving a dispute over a (possibly oral) private moneylending contract. The report ends by saying that the borrower must repay his debt because he had recently gotten a monetary reward by the local government that was more than twice the amount of the debt so he presumably had no reason not to repay his debt right away. The borrower was supposed to be “notified, so as to let him know about this” 告 [...] 令智 (知) 之. 146

141 The latter may be interpreted as a typical case of a "ritual sanctification of market practices" (Garraty 2010, 7).

142 Example from the Juyan frontier documents. See Scogin 1990, 1348.

143 Qianfu lun jian jiaozheng 19.226-232; Scogin 1990, 1367-1368.

144 Barbieri-Low and Yates 2015, 800-801 (no. 17 of the "Statutes on Households").

145 Terpstra 2019, 126, 129-130.

146 W. Chen 2012, 261 (no. 8-1008+8-1461+8-1532). 
As shown by a Han lawsuit recorded on documents excavated at Juyan, parties would also seek help from local government authorities in cases of dispute over the fulfilment of oral employment agreements. In this case, the dispute concerned the degree of authority of an agent employed with transporting and selling his client's 5,000 fish for 400,000 cash. With this assignment being made impossible due to an unexpectedly low market price for fish at the designated point of sale, the agent tried to mitigate the shortfall by various means including selling the ox that his client had given him in advance. The client yet charged him for not having fulfilled his obligations, which the agent denied. The final disposition of the case is somewhat unclear. ${ }^{147}$ In yet another case, the authorities ordered an agent to make a monetary compensation for the loss of his client's horse that had died under his custody while undertaking the task of catching a camel for the client. Because of the agent's incomplete payment, the plaintiff repeatedly called upon the government authorities in order to achieve the full compensation. ${ }^{148}$

The boundary between civil and criminal law has been a matter of debate. Similarly debated is the question of enforcement. It is not quite clear which ultimate measures the authorities would have taken to ensure compliance with court decisions in matters of interpersonal disputes over private contracts. ${ }^{149}$ At least in most cases, however, the highly active mediating role of the state in combination with reputational mechanisms likely functioned as an effective framework for contract enforcement.

\section{IV.4 Conclusion: Economic Impacts}

The high degree of standardization of imperial law and the empire-wide establishment of government offices with defined judiciary functions provided a relatively consistent set of rules and application across a vast space with the potential of reducing uncertainties and negotiation costs. Even though access to and benefit from judicature certainly was not equal to all members of society, hurdles do not seem to have been overly high, since reported judicial cases do include conflicts of relatively small scales in which people of relatively modest socioeconomic means seem to have relied on the judiciary institutions.

That the legal protection of private property rights in particular carried more importance in early imperial China than had been assumed before has been extensively demonstrated by legal and administrative documents excavated during the last couple of decades. While clarity of property rights was important to state insti-

147 On this case, see, for instance, Hulsewé 1979; Z. Zhang 2013, esp. 52-57; Scogin 1990, 13621365. A short summary is also provided by Ma, vol. 1, ch. 12.B, 537.

148 Z. Zhang 2013, 57-61; Scogin 1990, 1365.

149 For discussions of these questions, see Hulsewé 1979; Z. Zhang 2013; Scogin 1990, 1365, n. 93. 
tutions for fiscal reasons, the active mediation and enforcement of those rights by local government agencies must also have lowered risks and negotiation costs among the common people. Most importantly, the government agencies' role in the official notification of sales and in enhancing contract security likely entailed a considerable reduction of uncertainties within the range of property claims.

Yet it is also noteworthy to see which aspects were not or not extensively covered by early imperial law. In comparison to Roman law in particular, hitherto known legal statutes do not seem to have extensively covered questions of liability in principal-agent economic relationships. While corresponding disputes do show up in concrete judicial cases such as the ones mentioned above, the imperial statutes themselves appear not to have offered a robust legal framework for their handling. While one has to be cautious with regard to the possibility of future finds of legal statutes, the available evidence so far suggests that for more complex economic transactions such as long-distance trading activities, which demand control over the principal's and the agent's liabilities, the state's legal system did not play an important role in lowering transaction costs. The relative invisibility of private trading organizations in our sources apart from family networks, which had the potential to create reliable principal-agent relationships without the involvement of legal institutions, may be seen as a conspicuous reflection of this observation. ${ }^{150}$

\section{Standardization}

\section{V.1 Introduction}

Standardization was a key concern of Qin and Han rulers right from the start of the imperial period. The First Emperor of Qin's attempts in this regard are particularly famous. They are known both from historiographic sources and from inscriptions such as the following:

In the twenty sixth year [of his reign, $221 \mathrm{BCE}$ ], the Emperor entirely unified the feudal lords of the empire, brought great peace to the people, and assumed the title of the emperor. Therefore, he ordered his Grand Councillors Zhuang and Wan to standardise the measures and normalise those which were suspect to being irregular.

廿六年, 皇帝盡併兼天下諸侯, 黔首大安, 立號為皇帝。乃詔丞相狀、綰: 法度量則, 不壹㒸疑者, 皆明壹之。151

Inscriptions like this have been found - in a very standardized form themselves - on many scales and weights scattered all over the Qin Empire's territory. Standardization

150 On these matters, see Leese-Messing, ch. 15, IV.3, this volume.

151 Galambos 2004, 186. See also Loewe 2016, 180-181. 
was purposefully propagated as a sign of imperial sovereignty. ${ }^{152}$ Besides the weights and measures, the First Emperor also gets credited with an empire-wide standardization of the legal code, axle widths, and the script. ${ }^{153}$ Of course, the ideals of state propaganda need to be differentiated from actual practices on the ground. Furthermore, not all processes of standardization hinged upon state promulgation. It is yet undeniable that the early imperial era, including both the Qin and Han dynasties, was indeed a period of unprecedented standardization in a number of fields. Two spheres that underwent extensive standardization were those of law and of currency, which have been dealt with above. This section therefore explores three further fields of standardization that bore a potential to facilitate economic transactions: standardization of weights and measures, language and script, and consumption patterns.

\section{V.2 Weights and Measures}

As both transmitted and excavated texts and inscribed excavated artifacts suggest, a standard set of measuring units was commonly used across the Han Empire. ${ }^{154}$ This fact alone may be seen as an advantage compared to spaces where several competing sets of measures were used, since it made calculations relatively easy. Nevertheless, in finds of measuring instruments that indicate their supposed length, capacity, or weight, they vary to a certain extent. For instance, studies on the lengths of excavated linear measuring instruments from the Former and the Later Han periods have suggested coefficients of variation of 0.95 and 2.3 percent, respectively. ${ }^{155}$ People's experiences with de facto discrepancies may thus have left a certain degree of suspicion and uncertainty in many economic transactions, while the extent of this suspicion may have been limited in relation to the common range of rather moderate discrepancies.

That universal adherence to officially fixed norms was not always a matter of course is suggested by occasional references to situations or regions in transmitted texts in which people refused to stick to the standardized measures, and local officials needed to step in to restore order. ${ }^{156}$ Nevertheless, given the omnipresence of government institutions as supervisory authorities on official marketplaces as well as their frequent transactions with the common people in fiscal and other contexts, standard measures are likely to have been ubiquitous in the daily lives of people

152 Sanft 2014, 57-76. As a concrete example of this mindset, see Hanshu 21A.955.

153 Shiji 6.236-240, trans. Nienhauser 1994, 135-137.

154 For instance, the common units for capacity were yue 侖 (approx. 10ml), ge 合 (= 2 yue), sheng 升 (= $10 \mathrm{ge})$, dou (= $10 \mathrm{sheng})$; shi 石 or hu 斛 (= $10 \mathrm{dou}$ ), and those for (short) lengths were cun (approx. $2.31 \mathrm{~cm})$, chi 尺 (= $10 \mathrm{cun}), \mathrm{bu}$ 步 (= $6 \mathrm{chi})$, zhang 丈 (=10 chi).

155 As for the instruments of the short intermediary period of Wang Mang's reign, it is higher, 4.5 percent. Vogel 1996, 6, 23-27; based on Qiu 1992, 12-57. See further Bai 2015.

156 See, e.g., Loewe 2016, 163-164. 
across the empire. As such, they generally would have been a valid source for reliability with a considerable potential for lowering negotiation costs, also with regard to long-distance exchange.

\section{V.3 Language and Script}

With regard to linguistic standardization, it is crucial to differentiate between levels of standardization of the written language and its script on the one hand and spoken language on the other hand. Spoken ancient Chinese (or Sinitic) was a relatively uniform language during the Qin and Han periods. However, especially at the beginning of the early imperial period, non-Chinese languages were spoken by many local populations, particularly, but not only, on the empire's peripheries. With Chinese speakers assimilating these non-Chinese speakers in the course of the early empires' internal and external expansion, local populations often underwent wholesale language shifts to Chinese. This also resulted in so-called substratum effects on the Chinese language, which ultimately lead to the development of mutually incomprehensible Chinese dialects. These long-term diversifying effects, however, concern later periods much more than the Qin and Han periods themselves. ${ }^{157}$ But despite the relative uniformity of the Chinese language itself, and the considerable assimilation of originally non-Chinese speakers, bi- and multilingualism most likely were common phenomena especially in lower social strata. Curiously, the political and economic challenges that must have come along with widespread multilingualism were obviously regarded as such trivial matters by the political elite that they are rarely even hinted at by ancient historiographical sources. ${ }^{158}$

De facto multilingualism was not at all reflected by the written language, which was undisputedly Chinese across the entire space of the Qin and Han Empires. By the Han period, the Chinese written language (wenyán 文言) had already drifted away from colloquial usage to a certain extent, but in comparison to later periods still displayed many vernacular elements and was therefore not entirely alienated from common people's speaking habits. ${ }^{159}$ The written language was relatively uniform, but regional and stylistic scriptural variants existed and are likely to have caused problems in written communication, especially during the first decades of Han rule. ${ }^{160}$ This is also suggested by the fact that transmitted texts refer to a Han legal statute stipulating that officials were to be instantly punished for using nonstandard characters. ${ }^{161}$ Script variations never ceased to exist entirely during Han times, but excavated manuscripts suggest that their extent appears to have de-

157 Handel 2015.

158 Behr 2004, 182-185; Sanft 2019, 71-76.

159 Meisterernst 2015.

160 Galambos 2004.

161 Galambos 2004, 197-198. 
creased sufficiently so as to make mutual misunderstandings much less likely. ${ }^{162}$ Another notable observation in this regard is that excavated letters from the Han period share a very similar style and diction, even though they were found in places that were hundreds or thousands of kilometers apart. It has been suggested that these similarities speak in favor of "a unified empire-wide letter writing culture by mid-Han times," 163 which is likely to have greatly facilitated written communication across distant regions of the empire.

To summarize, one might say that with regard to both spoken and written language, early imperial China featured a relatively high degree of standardization in comparison to other geographically and demographically large ancient polities or macroregions. In general terms, this standardization, which affected both administrative and private (e.g., contractual) communication, bore the potential of lowering transaction costs with regard to regional and long-distance transactions. Literacy also appears to have increased to a certain extent during this period, which meant that people of relatively low social background (such as the huge number of people trained to work as scribes) could increasingly profit from the privilege that the ability to read and write meant for both bureaucratic careers and economic transactions. ${ }^{164}$ By contrast, for the many remaining non-Chinese speakers and illiterate people who could not afford scribal or translation services, this process of standardization is likely to have been a social and economic disadvantage.

\section{V.4 Consumption Patterns}

The four hundred years covered by the Qin and Han Empires were also marked by the gradual emergence of what may be called an 'imperial society' in a cultural sense. ${ }^{165}$ Factors such as the large-scale and long-distance, partly state-orchestrated migration of millions of people, ${ }^{166}$ the extension of physical infrastructure (see sec. VI), a high degree of geographic mobility of both high- and low-level state functionaries, increasingly standardized and state-promoted text corpora, and statemanaged production and distribution of high-quality luxury consumables, such as

162 See, for instance, the collections of variants for three Chinese characters found on stone inscriptions from the Han and the subsequent Three Kingdoms periods shown by Galambos 2004, 198. The variants do feature inconsistencies, but their extent is unlikely to have unsettled readers with some reading experience. See further Galambos and Hamar 2006; Kern 2002.

163 Giele 2015, 467. As Giele also points out, the few excavated letters from the Qin period show some obvious formal differences when compared to their Han counterparts.

164 On the question of literacy during the early imperial period, see, for instance, Sanft 2019; Yates 2011; Selbitschka 2018b; Barbieri-Low 2011.

165 For some typical aspects of elite cultural self-consciousness and their increasing coherence during the Han period, see Ebrey 1986, 643-646.

166 On the phenomenon of early imperial migration as evidenced in both historical and archaeological sources, see Korolkov and Hein 2020. 
lacquer tableware, contributed to a growing set of shared tastes and consumer needs, especially, but not only in higher social strata. Huge imperial banquets at the capital during which court luxuries were both shown off and gifted to participants from all over the empire and beyond, furthermore offered direct incentives for widespread elite emulation. ${ }^{167}$

Shared consumption patterns are most easily to be seen in funerary consumption. Han-style tomb assemblages found across the empire very typically include certain products such as bronze mirrors, S-shaped belt hooks, incense burners, and lacquer tableware, as well as burial objects such as figurines and ceramic models of daily-life scenes. Since large parts of Han-style tomb inventories are assemblages of items for daily use, they do not only attest shared aspects of funerary culture and beliefs, but also reflect common grounds in consumerism in more general terms, including shared tastes with regard to everyday items. ${ }^{168}$ Sure enough, these similarities must not be overgeneralized. Considering the fact that archaeological research in China has long been focused on sites such as extraordinary, lavishly equipped tombs while largely neglecting smaller tombs and settlements, the evidence is certainly biased toward elite consumption, which is inherently more likely to reveal patterns of convergence. Burials in frontier regions have furthermore often been interpreted with an underlying story line of one-sided acculturation of locals ('Sinicization'), whereas new research has shown that the situation on the ground was much more complex. ${ }^{169}$ Whereas future research in both of these areas is thus likely to bring to light important evidence for more social and regional variation, the high extent of similarities in consumption patterns at least among the higher social strata in the more central regions of the empire can hardly be neglected. Certain trends, such as the high-elite appreciation of steppe-style objects and artistic elements, or wider-spread waves of stylistic extravagance or simplicity, can also be determined not as local, but empire-wide phenomena. Widely shared consumption patterns and demands must therefore be acknowledged as an important factor to the wider spread of mass and modular production techniques in both state and private production, which then promoted consumptive standardization even further.

\section{V.5 Conclusion: Economic Impacts}

In all of the three fields discussed above, i.e., measures, language, and consumption patterns, the early imperial period was characterized by considerable levels of standardization, with the former two obviously superseding levels of the Mediterranean.

167 See Leese-Messing, ch. 6, II.1.3, this volume.

168 Erickson 2010; Shelach-Lavi 2015, 325-328.

169 Wu et al. 2019; Shelach-Lavi 2015, 328-336; Erickson, Yi, and Nylan 2010. 
Taken by themselves, these high levels of standardization would have to be taken into account as favorable preconditions for transaction cost reduction and economic exchange across larger spaces. Nevertheless, high standardization levels alone do not necessarily result in an increase in large-scale and long-distance trade. As the examples given for the Mediterranean region demonstrate, other factors are crucial in creating demand and opportunity for products such as 'bulk luxuries' to be traded in large quantities and over long distances, such as the distribution of resources and production facilities, as well as production techniques and their correlation to economies of scale. ${ }^{170}$ The interplay of all these and other factors with regard to certain products or production branches is in need of further specific research in order to better assess the impact of standardization levels in early imperial economic processes.

\section{Infrastructure}

Different components of physical infrastructure have always been crucial factors for interregional connectivity and economic integration. Major infrastructural investments necessarily entailed bundling resources on a grand scale. In early imperial China, centralized state power was essential in building up and expanding road and riverine networks through large-scale projects, which often needed tens of thousands of laborers and years of construction time. In addition to waterways and roads themselves, certain physical and intellectual components of supporting infrastructure created a functional network that enhanced interregional connectivity to unprecedented levels.

\section{VI.1 Waterways}

Scholars have often emphasized the fact that early imperial China was landlocked. In contrast to the Roman Empire and its maritime connectivity, it has been suggested that the Qin and Han Empires were essentially characterized by their geographically determined "tight spatial circumspection," which profoundly limited their fiscal and overall economic integration. ${ }^{171}$ According to this view, the Qin and Han

170 See Weaverdyck and Fabian, ch. 8.A, VI.3, this volume.

171 A recent and very explicit advocacy of this view is Lewis 2015. See also Adshead 1988, 15-16. Scheidel also emphasizes the lack of maritime connectivity as a key factor of differences between the Qin/Han and the Roman fiscal regimes, suggesting that "[i]n the Han system, which could not yet rely on the great canals of later dynasties, geography impeded massive transfer of staples" (2015, 180). On the issue of long-distance grain transport, see also Leese-Messing, ch. 15, IV.4, this volume. 
Empires resembled a mosaic of relatively isolated regions, with the capital and other cities largely depending on their own hinterlands, and long-distance transportation of bulk goods, especially grain, being a marginal feature.

New evidence in the form of excavated travel itineraries, distance tables, maps, and officials' travel diaries are challenging this view at least to a certain extent. They show that the riverine transportation system was much more important and efficient than has been assumed, and that the transportation of grain over large distances was quite a common phenomenon. The evidence further shows the scale of state involvement in securing both local and long-distance riverine infrastructure, and in the large-scale shipment of bulk commodities, particularly grain, which also took place between the two large river basins of the Yangzi in the south and the Yellow River in the north. ${ }^{172}$

The dense web of rivers in the south in particular provided ideal natural conditions for water transport. Both northern and southern waterways were further improved, for instance by massive canal construction projects during both the pre-imperial and early imperial periods, and allowed for highspeed travel already during Qin times. ${ }^{173}$ Han historians, too, attest to the fact that investing in riverine infrastructure was regarded as an essential part of state activity. The extensive chapters they dedicated to this matter include many examples of high-investment canal construction (for both transport and irrigation purposes) and other water management projects across the empire. ${ }^{174}$ Former Han legal statutes mention specialized boat crews employed by state institutions as well as state officials appointed to manage state-owned boats. ${ }^{175}$

Thanks to the discovery of Qin-era distance lists, we now have what appear to be quite reliable figures on the speed of southern riverine transport. ${ }^{176}$ The figures distinguish between speeds on major and minor rivers, during different seasons, upstream and downstream travel, as well as empty and loaded cargo status. The individual figures suggest an average downstream travel speed of approximately $54 \mathrm{~km}$ per day for major rivers, of $43 \mathrm{~km}$ per day with the inclusion of minor rivers, and an average upstream travel speed of 32 and $27 \mathrm{~km}$ per day, respectively. Riverine transport was therefore generally speedier than overland travel, as well as requiring less labor. ${ }^{177}$

Since almost all evidence we have on riverine infrastructure is related to state activity, we know a lot less about its use for private trade. Some administrative documents, however, offer glimpses into spheres in which state and private activi-

172 Korolkov 2020, ch. 5.

173 Korolkov 2020, 448-449.

174 On these chapters, see Leese-Messing, vol. 1, ch. 12.A, II.4.

175 Barbieri-Low and Yates 2015, 392-393, with n. 38 on 418.

176 The reliability of the Qin figures is suggested by the fact that they match very well with corresponding figures for the Tang period, which stem from an entirely independent source.

177 Korolkov 2020, 466-471. 
ties crossed. For instance, one document from the Qianling County archive (Liye) indicates that local government institutions may have been lending state-owned boats to private merchants. ${ }^{178}$ If this interpretation is correct, it would mean that state institutions even actively promoted private use of riverine infrastructure for trading purposes. In any case, the impression that private trade indeed relied heavily on riverine transport is also unambiguously conveyed by transmitted texts. For instance, this reliance is obvious from the fact that one of Emperor Wu's approaches to increasing fiscal revenues from commerce consisted in introducing a double-rate tax on merchants' vehicles, which explicitly included both carts and boats. ${ }^{179}$

\section{VI.2 Overland Routes}

Whereas the south had a natural advantage with regard to waterborne transport, the bulk of state investment into overland routes concerned the northern part of the empire, where the net of rivers was less dense. ${ }^{180}$ The centuries before the Qin and Han periods had been characterized by long and large-scale warfare, which facilitated the development of a road system that eventually linked all major cities even before the beginning of the imperial era. ${ }^{181}$ In the fourth century BCE, the expanding Qin state strategically built a set of roads that connected its center in the Guanzhong region with Shu (modern Sichuan) to its southwest, and the ensuing economic exploitation has often been described as one of the main factors for Qin's ultimate dominance over all the states to its east. ${ }^{182}$ During imperial times, both the Qin and Han regimes further expanded the system, e.g., by the famous 'Direct Road' (or 'Straight Road,' Zhidao 直道) that the First Emperor of Qin had his general Meng Tian 蒙恬 (d. 210 BCE) build from Ganquan (some $160 \mathrm{~km}$ northwest of the capital of Xianyang) northward to Jiuyuan (north of the Ordos loop). The primary incentive for this, too, was military logistics. ${ }^{183}$ The overall length of specially made roads has been estimated at ca. 35,000 km for the end of the Later Han period. ${ }^{184}$

178 W. Chen 2012, 72-76 (tablet 8-135); Korolkov 2020, 436.

179 Shiji 30.1430, trans. Watson 1993, 72.

180 This also explains why excavated legal statutes focus on regulations regarding overland rather than riverine transport, because the former demanded more input both in construction and control over efficient use. Korolkov 2020, 450, 464, 471.

181 Kiser and Cai 2003, 522 Some of the major long-distance routes were, however, already in use during the second millennium BCE. See Liu and Chen 2003, 50-56. For a map of the Warring States road network system, see Zhongguo gonglu jiaotong shi bianshen weiyuanhui 1994, 20-21. See also Feng 2006, 300-342.

182 E.g., Nylan 2012, 36.

183 On the 'Direct Road' see Shiji 6.256, trans. Nienhauser 1994, 148; Sanft 2011; 2014, 107-121; Sun 2018.

184 This would have meant a less dense road network than the Roman Empire. See, e.g., Adshead 1988, 15-16. See also Nylan 2012, 33-35, with a map of the early imperial road system on 34. 
During both Qin and Han times, the maintenance and expansion of the road system was essential for the empire's very survival, which depended heavily on the mobility of tax incomes, soldiers, conscript and convict laborers, state officials, and document couriers. State institutions did not only invest in the major roads of the highway system. Construction and annual maintenance of the simpler local roads and paths, bridges, and fords, belonged to the primary tasks of local labor levies and were officially declared to serve "the benefit of the counties' common people" 縣黔首利. ${ }^{185}$ Private initiatives certainly also played a considerable role in road maintenance (and even smaller-scale construction), even though the available source material rarely mentions them. ${ }^{186}$

The 'Direct Road' was only one of several 'highways' (chidao) that connected Xianyang (and the later Han capital Chang'an) with distant parts of the empire in all directions. At least parts of these highways were extremely broad, with transmitted sources mentioning a width of almost $70 \mathrm{~m}$, and the archaeologically studied sections being 45-50 m wide. ${ }^{187}$ The contemporary Chinese highways were typically made from several layers of rammed earth, which could have been advantageous with regard to their elasticity and resistance to various kinds of weather-induced deformations. ${ }^{188}$ Their surface engineering further may have been beneficial to the traveling speeds of oxcarts and foot porters alike. Early Han legal statutes expected loaded carts, empty carts, and foot porters to travel at a speed of $20.8 \mathrm{~km}, 29 \mathrm{~km}$, and $33.3 \mathrm{~km}$ per day, respectively. ${ }^{189}$

Apart from the size and quality of the road network, another important question concerns its users. The central lanes of highways were marked off by trees and walls, and strictly reserved for the emperor's travel alone, thus also serving to communicate imperial presence. Furthermore, at least during Qin and early Former Han times, side lanes of highways were officially reserved for authorized people (such as officials). There may have been additional outside lanes that could be used by other people, and illegal use of restricted lanes is also well attested for Han times. ${ }^{190}$ In any case, it seems likely that in a practical sense, lane restrictions mainly concerned the roads in and near the capital and maybe other larger cities. It can therefore be assumed that roads were highly frequented for nonofficial use, which likely included private trading activities to a large extent. This type of mobility across the road network was facilitated by the fact that the Han dynasty renounced custom

185 S. Chen 2015, 118 (slip 151); Korolkov 2020, 461-463.

186 Nylan 2012, 44.

187 Hanshu 51.2328 and 2329, n. 10; Z. Wang 1994, 256-258.

188 Needham and Ronan 1978, 1-2; Korolkov 2020, 455-456.

189 Barbieri-Low and Yates 2015, 902-903; Korolkov 2020, 440-461.

190 Sanft 2014, 106-107. In addition to the 'highways,' an excavated document from the Yuelu Academy collection also mentions "high-speed roads" (chong dao 衝道) as being reserved for use by high officials and military and labor conscripts. S. Chen 2017, 195-196 (slips 292-294); Korolkov 2020, 461. 
taxes at barriers and bridges early on, which reportedly prompted a considerable increase in merchant travel across the empire. ${ }^{191}$

\section{VI.3 Supporting Infrastructure}

The network of roads, rivers, and canals was accompanied by other state-run infrastructural facilities, including dense networks of granaries, guard posts, postal stations, and staffed travel accommodations for state officials at various convenience levels. Furthermore, the state heavily invested in the 'intellectual infrastructure' that was required for an efficient use of the existing physical infrastructure, e.g., by centrally coordinating the empire-wide fabrication and regular updating of local and regional maps and itineraries in order to gain and distribute reliable geographic knowledge. ${ }^{192}$ The truly imperial, supraregional scale of this mapping project may be illustrated by the find of an itinerary covering a route of more than $3,000 \mathrm{~km}$ between the southern county of Qianling (modern Liye, Hunan province), several hundred km south of the Yangzi, to Anyang county north of the Yellow River (in modern Henan). ${ }^{193}$

Certainly, the benefits of these surrounding and intellectual infrastructures were largely restricted to the economic and administrative activities of the state by securing the mobility of tax commodities, state functionaries, and information. It is much more difficult to know the extent to which they benefited the mobility of private traders. As for the geographic knowledge, it is to be assumed that it did not remain in closed bureaucratic circles, but also spread to other groups, such as those engaged in regional or supraregional trade. It is further easy to imagine that the state's security infrastructure in the form of guard posts (or 'police stations') may have had a stimulating effect on private business undertakings that involved travel beyond the local level, as long as these undertakings were themselves compatible with legal regulations.

The security offered by an imperial military presence alongside traveling routes in frontier regions such as the northwestern Hexi corridor may also be interpreted in this way. But according to our sources, the large groups of people that were traveling on these frontier roads and using the state's infrastructure of relay stations and accommodations were indeed not private traders, but state officials with their entourages as well as gigantic foreign diplomatic missions, which could easily comprise hundreds of individuals. ${ }^{194}$ The early Han legal statutes concerning the state's

191 Shiji 129.3261, trans. Watson 1993, 440.

192 On granaries, see, e.g., Nylan 2015, 108-113; Lee Kim 2016, 558-567; on the postal relay system, Lien 2015. On “intellectual infrastructure,” Korolkov 2020, 477-490.

193 Korolkov 2020, 487-488.

194 On the diplomatic missions as economic actors, see Leese-Messing, ch. 6, X, this volume. See also Leese-Messing, vol. 1, ch. 12.A, II.5. 
conveyance stations do not mention private customers except for the regulation that 'people employed in private capacity' 私使人 were strictly forbidden to be handed out food rations. ${ }^{195}$ Whether this also means that private people (such as traders) were not allowed to make use of the convenience stations at all, for example by paying for food or an overnight stay, is not quite clear. ${ }^{196}$ In the meticulous accounts of kitchen purchases, expenditures, and food recipients of the Xuanquan relay station, the only parties being served meals while not being classified as either messengers, officials, envoys, or their attendants, were the wife of a county chief, a "group of three, including messengers," a marquis and his large entourage, and a group of Qiang leaders. ${ }^{197}$ The Xuanquan documents so far do not indicate private traders to have been common customers of the station, even though some of the travelers on 'official business' may also have conducted trade along the way. ${ }^{198}$ Most private traders are likely to have been excluded from using these stations and would have had to use private lodging facilities, which definitely existed, but evidence on which is very limited.

But the official diplomatic missions to and from the Han court, which often involved massive, long-distance gift transfers, were also using these routes and were officially permitted to use the state's conveyance and other stations. This infrastructure can therefore be interpreted as an essential facilitator of long-distance movement of goods, even in exclusion of private trade. After all, both the legal statutes and the administrative documents from conveyance stations suggest that the easiest (if not the only) way of making use of the dense web of the state's traveling infrastructures - also for private trading activities - would have been to get hold of an official authorization to use them, that is, by being an official, by otherwise traveling on the state's official behalf, or by accompanying one of the former

195 Barbieri-Low and Yates 2015, 682-683 (no. 2 of the "Statutes on Food Rations at Conveyance Stations").

196 The possibility of paying money for food at conveyance stations is attested in the statute, but only under certain conditions. It stipulates that travelling officials or envoys who were for some reason not eligible to be served a free ration (for instance because they were not on official business just then), could buy food at the station on the basis of the 'fair-market price.' Whether this possibility also existed for people without any official affiliation is not mentioned by the statute.

197 Lee Kim 2016, 575-579. The centrally organized system of relay stations in the Achaemenid Empire that has been reconstructed on the basis of the Travel Rations compares in many ways with the Han system. For the Achaemenid system, see Briant 2012. For some comparisons with the relay system on Roman roads, see Kolb and Speidel 2015, 139-140.

198 J. Yang strongly argues that "the Xuanquan manuscripts have provided indisputable evidence that many of the 'envoys' were actually merchants” (2015, 429). The 'envoys' in his central example deliver camels as 'gifts' by the kings of Kangju and Suxie to the Han governor of Jiuquan (in the Hexi corridor), and the latter turns out to be dissatisfied with the quality of the animals. Yang interprets this instance as a typical example of diplomacy being used as what Yü (1967) had famously coined a 'cloak for trade.' This might have been the case, but the document does not show this as 'indisputably' as Yang suggests. For instance, the document does not bear any evidence for Yang's argument that "the Han government clearly paid for the camels.” 
two as their acknowledged 'attendant.' It is therefore possible that it was these groups of people that were particularly likely to engage in long-distance trade either on their own or a client's behalf - at least on routes where other means of lodging and feeding oneself and one's pack or draft animals were scarce or unavailable.

\section{VI.4 Prospects}

Future archaeological excavations in the context of the physical infrastructural network, alongside a more systematic interpretation and regional specification of both archaeological and textual evidence, promise to bring new breakthroughs for a better understanding of infrastructural connectivity in the near future. As for the current trend, recent research suggests that whereas many hinterland populations and resources were difficult or even impossible to access for topographic and other reasons, this did not mean regional isolation. The well-established infrastructural network of the early empires, including its potential for long-distance transport of grain and high-value commodities, was an important foundation for enhanced interregional and inter-imperial connectivity. ${ }^{199}$

\section{Technology}

\section{VII.1 Introduction}

The Han period has long been credited as one of the important phases in Chinese history with regard to technological advancement. ${ }^{200}$ From a theoretical point of view, larger underlying historical developments may be considered to be potential facilitators of such a general trend. First, the early imperial period succeeded an era that was essentially characterized by long and intensive interstate competition, which has often been claimed as a major promoter of technological innovation. And second, at least some of the Han rulers themselves were technophilic enough to promote technological innovation on a wide geographic scale. This personal interest, combined with a strong intellectual current toward the quantifiability of production in administrative contexts, made the Han state a facilitating factor in the diffusion and further development of certain technologies. ${ }^{201}$ But how these preconditions actually affected individual technologies, and which economic significance

199 Korolkov 2020, 548-551.

200 E.g., Needham and Wang 1954, 111-112.

201 On the importance of these two factors for technological developments in medieval Europe and in Tang/Song China, respectively, in contrast to the Roman Empire, see Terpstra 2020. 
can be associated with the latter, needs to be reassessed on an individual basis. Three examples will be introduced in what follows: metallurgy, agriculture, and silk weaving. In all three cases, both pre-imperial technological foundations as well as early imperial state sponsorship play important roles. Driven by its fiscal interest in each of the branches, the government used its infrastructural power to propel technological change. While the technologies were characterized by highly different material and structural affordances, all three of them can be associated with significant economic ramifications.

\section{VII.2 Metallurgy}

Both wrought and cast iron had been produced in the centuries predating the Qin and Han periods. ${ }^{202}$ The widespread use of iron implements as well as some crucial technological developments, however, characterized the time from the third century BCE onward and the Han period in particular. The third century BCE witnessed a development toward large-scale iron production in the hands of wealthy private entrepreneurs running 'iron plantations' with hundreds of or even more than a thousand laborers, with the facilities typically located close to mountains and forests that provided a reliable supply of charcoal. ${ }^{203}$ The technological advances in iron casting technology, especially the ability to produce malleable cast iron, and the introduction of blast furnaces, which radically superseded the older technology of bloomery smelting, were crucial for moving toward mass production. ${ }^{204}$

Under the reign of Emperor $\mathrm{Wu}$, this well-established industry, technologically equipped for concentrated large-scale iron production, met with the interests of an interventionist government eager to secure new sources of revenue for large-scale military campaigns, to enhance agricultural production, and to break the power of the local wealthy. The result of this politico-technological concurrence was the aforementioned establishment of a total state monopoly of the iron industry in 117 BCE, under which both private production and sale of iron were prohibited. ${ }^{205}$

The Hanshu localizes 48 'iron offices' spread across Han territory, which most likely took the form of large ironwork facilities, using the labor of hundreds of convicts and others each. ${ }^{206}$ Several of these are indicated as places of production in

202 Wagner 2008, 83-114.

203 Wagner 2008, 140-147.

204 On the invention, spread, technological details, and benefits of malleable cast iron, see Wagner 2008, 114, 159-169. With regard to Europe, malleable cast iron is known as an invention of the seventeenth century, and became industrially important in the nineteenth century. Wagner 2008, 167. On the technology of early imperial blast furnaces, see Wagner 2008, 231-237.

205 See sec. II.3.5 above.

206 Wagner 2001, 38-52. 
inscriptions on excavated iron tools. ${ }^{207}$ Emperor $\mathrm{Wu}$ appointed an experienced iron entrepreneur to be in charge of the monopolization of the industry and sent him across the empire in order to establish iron offices staffed by other successful local ironmasters. ${ }^{208}$ This purposeful inclusion of established specialists must have been crucial for the transfer of expert knowledge, including technological expertise.

It is interesting that most excavated blast furnaces date from the period after the establishment of the monopoly. Even though other potential factors may also play a role in this observation, such as the regionally and geographically unequal distribution of previous excavations, it also might be an indication of the state monopoly being an important stimulator for large-scale iron production and technology diffusion. 209

\section{VII.3 Agricultural Tools and Cultivation Methods}

Widespread use of iron agricultural tools among the common peasant population is attested archaeologically and historically from the third century BCE onward. It must have meant a considerable facilitation of agricultural work and an increase in productivity in general. Active intervention by the Han government may have further promoted this development, such as the monopolization of the iron industry and its attempts to spread iron implements throughout its populace and keeping their prices low. ${ }^{210}$ While the often-quoted ancient critics of the monopoly who said that state-produced iron implements lacked quality and variety are not to be neglected, they must be seen in their polemic context. They are, after all, not supported by the archaeological evidence. ${ }^{211}$

There were considerable changes not only regarding the material, but also the technology of farming tools. Simple version of moldboard or turn plows had already

207 See the list in Wagner 2001, 89-99.

208 The scarce evidence for the Later Han period suggests that the highest posts in iron offices were by that time filled by bureaucrats rather than by entrepreneurs. Wagner 2001, 45 .

209 It is also worth noting that many of the ironworks were located close to contemporary cities, which would hardly have been first-choice locations from an economic or environmental perspective, but only make sense from an administrative point of view. One needs to consider, however, that the fact that many facilities have been found near ancient cities is also connected to the fact that the latter are often located in or nearby modern cities, and that sites are more likely to be discovered there than, for instance, those in remote, mountainous areas. Wagner 2001, 36-38.

210 Bray 1979, 5.

211 Wagner correctly argues that generalizing interpretations on the basis of the ancient critics' statements, such as Nishijima's assertion that "iron implements manufactured under the state iron monopoly were too large for practical use" (Nishijima 1986, 563), are highly unconvincing. Also, during the second century CE, Cui Shi, in a critique of contemporary state-produced iron implements, refers to earlier state-produced products as being of such high quality that they were "famous throughout the empire." This suggests that product quality fluctuated over time, and state products were not generally regarded as being of low quality. Wagner 2001, 25 (n. 13), 56-62. 
been in use in pre-imperial times, but became more common and sophisticated during Han times. They could be drawn by one or two oxen even on heavy soil. Their efficiency was increased by features such as a dished, cast-iron moldboard and an adjustable sheath for regulating plowing depth. Their design reduced friction to an extent suggested to be unequaled in Europe until the eighteenth century. ${ }^{212}$ Furthermore, oxen-drawn, multitube seed drills were introduced during the first century of Han rule, which enabled a precise planting of seeds in several ridges at the same time. Another agro-technological novelty of the Former Han period was the rotaryfan winnowing machine, several pottery models of which have been found in tombs in different regions of the Han Empire. A crank-operated fan at the end of a sloping tunnel blew away chaff and bran (which could further be separated by some of the machines), letting only the heavier grain fall below the hopper through which it was poured. This technology, the first European evidence for which dates from the seventeenth century, made winnowing many times more efficient than shovels or baskets. It must have meant enormous labor-saving for those who could afford the device. $^{213}$

Several new cultivation methods were tested and put into practice during the Han period, the most famous ones being a ridge-and-furrow system called the 'alternating fields' (daitian 代田) method, which economized on seeds and facilitated the thinning and spacing of plants, and a method of 'pit-cultivation' (ouzhong 區種). Both were intensively tested and promoted by the central Han government and reportedly resulted in extraordinary yield increases. ${ }^{214}$

While it is difficult to assess the overall economic effect of new farming techniques and tools, taken together they likely contributed to an increase in per capita productivity at least in certain regions. As for the social effects, the new cultivation methods are likely to have benefited large landowners more than common farming households, since both of them required high investments in either livestock and new equipment (i.e., large and heavy moldboard iron plows and the newly invented seed-drills) in the case of the daitian method, or in human labor in case of the ouzhong method. That the government provided farmers with tools and draught animals on loan, may have worked against this imbalance to a certain degree, but are unlikely to have compensated for the relative disadvantage to small peasant households.

\section{VII.4 Silk Weaving Technology}

Technological sophistication of another kind and with very different economic implications concerns the production of silk fabrics. Indications for Han consumerism

212 On Han ploughs, see Bray and Needham 1984, 169-196.

213 On the winnowing machines, see Bray and Needham 1984, 366-381; Vogel 2006.

214 In Guanzhong, the daitian method reportedly increased yields by at least one bushel per $m u$, up to doubled yields. Its use became especially widespread in the Guanzhong area and in agricul- 
in high elite and even middling social strata are typically associated with a heightened demand for luxury textiles. ${ }^{215}$ Even though luxurious and technologically sophisticated types of patterned silk cloth, such as $q i$ 綺 and jin 錦 fabrics, $^{216}$ had already been produced during pre-imperial times, they were apparently produced on much larger scales during the Han period. The technology of looms seems to have kept up with this heightened demand for extremely high-quality textiles and for woven textile patterning with lively pictorial images in particular. These increasingly replaced silk embroidery and painting, which had characterized luxury textiles during the Warring States and the early Han era. ${ }^{217}$ For instance, treadleoperated looms with multiple, quickly operating shafts and treadles offering an "advanced and highly efficient patterning equipment" were used by Later Han times for the production of the polychrome jin silks. ${ }^{218}$ And the highly complex drawloom, described by a contemporary as a "supernatural machine” (deng shen ji 登神幾), probably replaced the pattern-rod loom in Later Han times as a result of higher economic demands. ${ }^{219}$

Technological advancement in this case did not mean a potential for extended availability in a social sense. The complex looms required highly qualified weavers and considerable financial investment, which restricted their operation to largescale workshops and state-run textile production centers in particular. ${ }^{220}$ State workshops are known to have produced luxury silk fabrics for consumption in imperial palaces and redistribution to high elite circles, including large-scale exports in the context of diplomatic relations. The highly advanced technological finesse of largely state-produced jin silks was obvious to viewers and consumers both within and far beyond the cultural sphere of the Han Empire's core region. Technological advancement in silk production must therefore be considered as one central factor for Han jin silks to be appreciated as prestige goods across the Eurasian region, which was the essential precondition for them to find their ways to places such as the Tarim Basin polities and eventually as far as Palmyra. 221

tural garrisons (tuntian) along the northwestern frontier. Especially in drier regions, the success of the system, which relied on deep plowing, depended on the maintenance of reliable irrigation systems. Bray 1979, 5-6.

215 See Leese-Messing, ch. 15, III.2, this volume.

216 Qi silk was a "technologically sophisticated, monochrome, patterned, damask-like weave," while jin silk was an "even more complex polychrome, patterned, warp-faced, compound tabby weave.” Selbitschka 2018a, 22.

217 Models of four complex weaving looms for the production of sophisticated jin silks have been found in a second-ncentury BCE tomb in Chengdu (in modern Sichuan). See Chengdu wenwu kaogu yanjiusuo et al. 2014.

218 Kuhn 1995, 90-92.

219 Kuhn 1995, 95-102.

220 Kuhn 1995, 102.

221 Selbitschka 2018a. 


\section{Conclusion}

The economic tools discussed in this chapter essentially suggest three more general observations. First, in all the discussed spheres, the early imperial period witnessed institutional and structural developments that substantially enhanced opportunities for increased economic activity and connectivity. Second, the role of state institutions in providing and promoting these tools suggests to have been relatively active, also in comparison to other contemporaneous societies. This picture may be biased to a certain degree, however, because of a likely underrepresentation in our sources of the economic tools of, for instance, private trading networks. And third, the comparatively active role of state institutions in economic matters (as consumers, producers, distributors, and regulators), as well as concrete observations with regard to certain toolsets (e.g., the tendency of the fiscal system to distribute tax burdens and to cap private capital accumulation to a certain degree, as well as the limitations observed with regard to the credit system and agency law), point toward the understanding that the ensemble of economic tools in early imperial China presented in this chapter may have promoted both extreme private capital accumulation and massive long-distance private trading activities to a lesser extent than suggested in the case of the Roman world.

\section{References}

Adshead, S. A. M. 1988. China in world history. 3rd ed. London: Palgrave Macmillan.

-. 2004. T'ang China: The rise of the east in world history. London: Palgrave Macmillan.

Bai, Y. 2015. "The studies on the measuring devices of the Han dynasty and the relevant issues." Chinese Archaeology 15.1, 188-194.

Bang, P. F. 2009. "Commanding and consuming the world: Empire, tribute, and trade in Roman and Chinese history." In W. Scheidel (ed.), Rome and China: Comparative studies in ancient world empires, 100-120. Oxford: Oxford University Press.

Barbieri-Low, A. J. 2007. Artisans in early imperial China. Seattle, WA: University of Washington Press.

-. 2011. "Craftsman's literacy: Uses of writing by male and female artisans in Qin and Han China." In L. Feng and D. P. Branner (eds.), Writing and literacy in early China: Studies from the Columbia Early China Seminar, 370-400. Seattle, WA: University of Washington Press.

Barbieri-Low, A. J. and R. D. S. Yates. 2015. Law, state, and society in early imperial China: A study with critical edition and translation of the legal texts from Zhangjiashan tomb no. 247.2 vols. Leiden: Brill.

Behr, W. 2004. “'To translate' is 'to exchange' 譯者言易也 - Linguistic diversity and the terms for translation in ancient China." In N. Vittinghoff and M. Lackner (eds.), Mapping meanings: The field of New Learning in late Qing China, 173-209. Leiden: Brill.

Bielenstein, H. 1980. The bureaucracy of Han times. Cambridge: Cambridge University Press.

Bray, F. 1979. "Agricultural technology and agrarian change in Han China." Early China 5, 3-13.

Bray, F. and J. Needham. 1984. Science and civilisation in China. Vol. 6, Biology and biological technology. Part 2, Agriculture. Cambridge: Cambridge University Press. 
Bresson, A. 2021. "Metal-object currency before coinage: China and the West." In L. Rahmstorf, G. Barjamovic, and N. Ialongo (eds.), Merchants, measures and money: Understanding technologies of early trade in a comparative perspective, 289-303. Kiel: Wachholtz.

Briant, P. 2012. "From the Indus to the Mediterranean: The administrative organization and logistics of the great roads of the Achaemenid Empire." In S. E. Alcock, J. Bodel, and R. J. A. Talbert (eds.), Highways, byways, and road systems in the pre-modern world, 185201. Malden, MA: Wiley-Blackwell.

Cang Zhifei 蔵知非. 2012. Qin Han fuyi yu shehui kongzhi 秦漢賦役與社會控制 [Qin and Han taxation and social control]. Xi'an: Sanqin chubanshe.

Chen Songchang 陳松長, ed. 2017. Yuelu shuyuan cang Qin jian 岳麓書院藏秦簡 [Qin bamboo slips from the Yuelu Academy collection]. Vol. 5. Shanghai: Shanghai cishu chubanshe.

-. 2015. Yuelu shuyuan cang Qin jian 岳麓書院藏秦簡 [Qin bamboo slips from the Yuelu Academy collection]. Vol. 4. Shanghai: Shanghai cishu chubanshe.

Chen Wei 陳偉, ed. 2012. Liye Qin jiandu jiaoshi 里耶秦简片卖校释 [Annotated edition of the Qin documents on wooden slips from Liye]. Vol. 1. Wuhan: Wuhan daxue chubanshe.

Chengdu wenwu kaogu yanjiusuo 成都文物考古研究所 et al. 2014. “Chengdushi Tianhuizhen Laoguanshan Han mu” 成都市天回镇老官山汉墓 [A Han tomb at Laoguanshan near the Tianhui hamlet in Chengdu]. Kaogu 考古, no. 7, 59-70.

Coşgel, M. M. and T. J. Miceli. 2009. "Tax collection in history." Public Finance Review 37.4, 399420.

Ebrey, P. 1986. "The economic and social history of Later Han." In D. Twitchett and M. Loewe (eds.), The Cambridge history of China, vol. 1, 608-648. Cambridge: Cambridge University Press.

Erickson, S. N. 2010. "Han dynasty tomb structures and contents." In M. Nylan and M. Loewe (eds.), China's early empires: A re-appraisal, 13-82. Cambridge: Cambridge University Press.

Erickson, S. N., S. Yi, and M. Nylan. 2010. "The archaeology of the outlying lands." In M. Nylan and M. Loewe (eds.), China's early empires: A re-appraisal, 135-168. Cambridge: Cambridge University Press.

Feng, L. 2006. Landscape and power in Early China. The crisis and fall of the Western Zhou 1045771 BC. Cambridge: Cambridge University Press.

Galambos, I. 2004. "The myth of the Qin unification of writing in Han sources." Acta Orientalia Academiae Scientiarum Hungaricae 57.2, 181-203.

-. 2006. Orthography of early Chinese writing: Evidence from newly excavated manuscripts. Budapest: Department of East Asian Studies, Eötvös Loránd University.

Gale, E. M., trans. 1967. Discourses on salt and iron: A debate on state control of commerce and industry in ancient China, Chapters I-XXVIII. Taipei: Ch'eng Wen.

Gao Dalun 高大倫. 1998. “Yinwan Han mu mudu 'jibu' zhong hukou tongji ziliao yanjiu” 尹灣漢墓木牘·集簿’中戶口統計資料研究 [A study of the household statistics in the 'collected registers' on a wooden tablet from the Han burial at Yinwan]. Lishi yanjiu 历史研究, no. 5, 110-123.

Gao Min 高敏. 2003. “Cong Zhangjiashan Han jian ‘Ernian luling' kan Xi-Han qianqi de tudi zhidu: Du 'Zhangjiashan Han mu zhujian' zhaji zhi san” 從張家山漢簡《二年律令》看西漢前期的 土地制度：讀《張家山漢墓竹簡》札記之三 [The Han-period ‘Ernian Lüling’ slips from Zhangjiashan as evidence for the early Western Han system of land tenure]. Zhongguo jingji shi yanjiu 中国经济史研究, no. 3, 143-147.

Garraty, C. P. 2010. "Investigating market exchange in ancient societies: A theoretical review." In C. P. Garraty and B. L. Stark (eds.), Archaeological approaches to market exchange in ancient societies, 3-32. Boulder, CO: University Press of Colorado.

Giele, E. 2015. "Private letter manuscripts from early imperial China." In A. Richter (ed.), A history of Chinese letters and epistolary culture, 399-474. Leiden: Brill. 
Han Shufeng 韓樹峰. 2011. “Qin Han tuxing jiegou” 秦漢徒刑結構 [The structure of penal labor during Qin and Han times]. In Han Wei falü yu shehui: Yi jiandu, wenshu wei zhongxin de kaocha 漢魏法律與社會: 以簡牘、文書為中心的考察, 49-76. Beijing: Shehui kexue wenxian chubanshe.

Handel, Z. 2015. "Dialect diversification, major trends." Encyclopedia of Chinese language and linguistics online. Brill. http://dx.doi.org/10.1163/2210-7363_ecll_COM_000303.

Hanshu 漢書 [Documents of the Han]. 1962. Composed by Ban Gu 班固 (32-92 CE). Beijing: Zhonghua shuju.

Hinsch, B. 1998. “Women, kinship, and property as seen in a Han dynasty will.” T'oung Pao 84.1, $1-20$.

Hou Chunping 侯春平. 2014. “Qin Han caichan sunhai peichang falü zhidu kaozheng” 秦漢財產損害賠償法律制度考證 [A study of the legal regulations on property damage reimbursement during Qin and Han times]. Lantai shijie 蘭台世界 27, 22-23.

Hou Hanshu 後漢書 [Documents of the Later Han]. 1965. Composed by Fan Ye 范曄 (398-445 CE). Beijing: Zhonghua shuju.

Hsing, I-tian 邢義田. 2014. “Qin-Han census and tax and corvée administration: Notes on newly discovered materials.” In Y. Pines, G. Shelach, L. Falkenhausen, and R. D. S. Yates (eds.), Birth of an empire: The state of Qin revisited. Berkeley, CA: University of California Press.

-. 2017. “Zailun sanbian quan: Du Yuelu shuyuan cang Qin jian zhaji zhi si” 再論三辨券: 讀岳麓 書院藏秦簡札記之四 [A rediscussion of tripartite tallies: Reading notes on the Qin Documents from the Yuelu Academy Collection, part four]. Jianbo 簡帛 14, 29-35.

Hsu, C. 1980. Han agriculture: The formation of the early Chinese agrarian economy (206 BC$A D$ 220). J. L. Dull (ed.). Seattle, WA: University of Washington Press.

Hulsewé, A. F. P. 1978. “'Contracts' of the Han period.” In L. Lanciotti (ed.), Il diritto in Cina, 1138. Florence: Leo S. Olschki.

-. 1979. “A lawsuit of AD 28.” In W. Bauer (ed.), Studia sino-mongolica: Festschrift für Herbert Franke, 23-34. Wiesbaden: Franz Steiner.

-. 1985a. Remnants of Ch'in law: An annotated translation of the Ch'in legal and administrative rules of the 3rd century BC discovered in Yün-Meng Prefecture, Hu-Pei Province, in 1975. Leiden: Brill.

-. 1985b. "The influence of the 'legalist' government of Qin on the economy as reflected in the texts discovered in Yunmeng county.” In S. R. Schram (ed.), The scope of state power in China, 211-235. London: School of Oriental and African Studies.

-. 1988. “The wide scope of tao 盗 'theft,' in Ch'in-Han law.” Early China 13, 166-200.

Kakinuma Yōhei 柿沼陽平. 2015. Chūgoku kodai no kahei 中国古代の貨幣 [The currencies of ancient China]. Tokyo: Yoshikawa Hironikan.

Katō Shigeru 加藤繁. 1952. “Kandai ni okeru kokka zaisei to teishitsu zaisei to no kubetsu” 漢代に於ける国家財政と帝室財政との区別 [The division between the public and the privy purse during the Han dynasty].” In Shina keizaishi kōshō 支那経済史考証. Tokyo: Tōyō bunko.

Kern, M. 2002. "Methodological reflections on the analysis of textual variants and the modes of manuscript production in early China." Journal of East Asian Archaeology 4.1, 143-181.

Kiser, E. and Y. Cai. 2003. "War and bureaucratization in Qin China: Exploring an anomalous case." American Sociological Review 68.4, 511-539.

Kolb, A. and M. A. Speidel. 2015. "Perceptions from beyond: Some observations on non-Roman assessments of the Roman Empire from the great eastern trade routes." Journal of Ancient Civilizations 30, 117-149.

Korolkov, M. 2012. “Greeting tablets' in early China: Some traits of the communicative etiquette of officialdom in light of newly excavated inscriptions." T'oung Pao 98.4/5, 295-348.

-. 2015. "Convict labor in the Qin Empire: A preliminary study of the 'registers of convict laborers' from Liye.” In Fudan daxue lishi xi 復旦大學歷史學系 et al. (eds.), Jianbo wenxian yu gudai 
shi: Di er jie chutu wenxian qingnian xuezhe guoji luntan lunwenji 簡帛文獻與古代史:

第二届出土文獻青年學者國際論壇論文集, 132-156. Shanghai: Zongxi shuju.

-. 2016. "Calculating crime and punishment: Unofficial law enforcement, quantification, and legitimacy in early imperial China." In "The New Ancient Legal History." Special issue, Critical Analysis of Law 3, 70-86.

-. 2020. "Empire-building and market-making at the Qin frontier: Imperial expansion and economic change, 221-207 BCE.” PhD diss., Columbia University.

-. 2021a. "Between command and market: Credit, labour, and accounting in the Qin Empire (221207 BCE)." In E. Sabattini and C. Schwermann (eds.), Between command and market: Economic thought and practice in Early China, 160-241. Leiden: Brill.

-. 2021b. "Fiscal transformation during the formative period ancient Chinese empire (late fourth to first century BCE)." In J. Valk and I. S. Marín (eds.), Ancient taxation: The mechanics of extraction in comparative perspective, 203-261. Albany, NY: State University of New York Press.

Korolkov, M. and A. Hein. 2020. "State-induced migration and the creation of state spaces in early Chinese empires: Perspectives from history and archaeology." Journal of Chinese History, 1-23. https://doi.org/10.1017/jch.2020.45.

Kuhn, D. 1995. "Silk weaving in ancient China: From geometric figures to patterns of pictorial likeness." Chinese Science 12, 77-114.

Lau, U. and M. Lüdke. 2012. Exemplarische Rechtsfälle vom Beginn der Han-Dynastie: Eine kommentierte Übersetzung des Zouyanshu aus Zhangjiashan/Provinz Hubei. Tokyo: Research Institute for Languages and Cultures of Asia and Africa, Tokyo University of Foreign Studies.

Lau, U. and T. Staack. 2016. Legal practice in the formative stages of the Chinese Empire: An annotated translation of the exemplary Qin criminal cases from the Yuelu Academy Collection. Leiden: Brill.

Lee Kim, M. 2016. "Discrepancy between laws and their implementation: An analysis of granaries, statutes, and rations during China's Qin and Han periods." Journal of the Economic and Social History of the Orient 59.4, 555-589.

Lewis, M. E. 2015. "Early imperial China, from the Qin and Han through Tang." In A. Monson and W. Scheidel (eds.), Fiscal regimes and the political economy of premodern states, 282-307. Cambridge: Cambridge University Press.

Li, C. 2019. "The system of tribute equalisation in the Han." In L. Cheng, T. Peach, and F. Wang (eds.), The political economy of the Han dynasty and its legacy, 101-114. London: Routledge.

Li Yiming 李一鸣. 2018. “Shilun Han dai de minjian jiedai xisu yu guanfang zhixu 试论汉代的民间借贷习俗与官方秩序 [A preliminary discussion of people's lending practices and their treatment by the state during the Han period].” Minsu yanjiu 民俗研究, no. $1,78-88$.

Lianyungang shi bowuguan 連雲港市博物館 et al. 1997. Yinwan Han mu jiandu 尹灣漢墓簡牘 [Bamboo and wooden documents on from the Han tomb at Yinwan]. Beijing: Zhonghua shuju.

Lien, Y. E. 2015. "Reconstructing the postal relay system of the Han period." In A. Richter (ed.), $A$ history of Chinese letters and epistolary culture, 17-52. Leiden: Brill.

Liu, L. and X. Chen. 2003. State formation in early China. London: Duckworth.

Loewe, M. 1967. Records of Han administration. 2 vols. Cambridge: Cambridge University Press.

-. 2016. Problems of Han administration: Ancestral rites, weights and measures, and the means of protest. Leiden: Brill.

Meisterernst, B. 2015. "Warring states to medieval Chinese." Encyclopedia of Chinese language and linguistics online. Brill. http://dx.doi.org/10.1163/2210-7363_ecll_COM_00000445.

Miyake Kiyoshi 宮宅潔. 2013. “Han dai guanliao zuzhi de zuixia ceng: 'guan' yu ‘min' zhijian” 漢代官僚組織的最下層:‘官”與“民”之間 [The lowest tier of the Han bureaucratic organization: Between 'officials' and 'people']. Zhongguo gudai falü wenxian yanjiu 中國古代法律文獻研究, no. 7, 127-161. 
-. 2016a. “Laoyixing tixi de jiegou yu bianqian” 勞役刑體系的結構與變遷 [Structure and development of the system of convict labor]. In Yang Zhenhong 楊振紅 (trans.), Zhongguo gudai xingzhi shi yanjiu 中國古代刑制史研究 [Studies in ancient China's penal system], 60158. Guilin: Guangxi shifan daxue.

-. 2016b. “Sikong xiaokao: Qin Han shiqi xingtu guanli zhi yi ban” 司空小考: 秦漢時期刑徒管 理之一斑 [A study on the office of controller of works: Management of convicts during the Qin and Han periods]. In Yang Zhenhong 楊振紅 (trans.), Zhongguo gudai xingzhi shi yanjiu 中國古代刑制史研究, 188-243. Guilin: Guangxi shifan daxue.

Momiyama Akira 籵山明. 1998. “Kechi jiandu chutan: Han jian xingtai lun” 刻齒簡牘初探: 漢簡 形態論 [A preliminary examination of bamboo and wooden documents with notches: On the form of Han documents].” In Zhongguo shehui kexueyuan jianbo yanjiu zhongxin 中國社會 科學院簡帛研究中心 (ed.), Jianbo yanjiu yicong 簡帛研究譯叢, 147-177. Changsha: Hunan renmin chubanshe.

Needham, J. and C. A. Ronan. 1978. The shorter science and civilisation in China. Vol. 5. Cambridge: Cambridge University Press.

Needham, J. and L. Wang. 1954. Science and civilisation in China. Vol. 1, Introductory orientations. Cambridge: Cambridge University Press.

Nienhauser, W. H., ed. 1994. The Grand Scribe's records. Vol. I, The basic annals of pre-Han China. Bloomington, IN: Indiana University Press.

Nishijima, S. 1986. "The economic and social history of Former Han.” In D. Twitchett and M. Loewe (eds.), The Cambridge history of China, vol. 1, 545-607. Cambridge: Cambridge University Press.

Nylan, M. 2012. “The power of highway networks during China's classical era (323 BCE-316 CE): Regulations, metaphors, rituals, and deities." In S. E. Alcock, J. Bodel, and R. J. A. Talbert (eds.), Highways, byways, and road systems in the pre-modern world, 33-65. Malden, MA: Wiley-Blackwell.

-. 2015. "Supplying the capital with water and food." In M. Nylan, G. Vankeerberghen, and M. Loewe (eds.), Chang'an 26 BCE: An Augustan age in China, 99-130. Seattle, WA: University of Washington Press.

Peng, K. 2000. “Coinage and commercial development in Eastern Zhou China.” PhD diss., University of Chicago.

Peng, X. 1994. A monetary history of China. E. H. Kaplan (trans.). 2 vols. Bellingham, WA: Western Washington University.

Qianfu lun jian jiaozheng 潛夫論箋校正 [Comments of a Recluse with collated commentaries]. Composed by Wang Fu 王符 (ca. 85-163 CE). Collation of commentaries by Wang Jipei 汗繼培 and Peng Duo 彭鐸. Beijing: Zhonghua shuju, 1997.

Qiu Guangming 丘光明. 1992. Zhongguo lidai duliangheng kao 中國歷代度量衡考 [Investigations into the length, capacity and weight measures of China through the ages]. Beijing: Kexue chubanshe.

Sanft, C. 2011. "Debating the route of the Qin Direct Road (Zhidao): Text and excavation." Frontiers of History in China 6.3, 323-346.

-. 2014. Communication and cooperation in early imperial China: Publicizing the Qin dynasty. Albany, NY: State University of New York Press.

-. 2019. Literate community in early imperial China: The northwestern frontier in Han times. Albany, NY: State University of New York Press.

Scheidel, W. 2008. "The divergent evolution of coinage in eastern and western Eurasia." In W. V. Harris (ed.), The monetary systems of the Greeks and Romans, 267-286. Oxford: Oxford University Press.

-. 2009. "The monetary systems of the Han and Roman Empires." In W. Scheidel (ed.), Rome and China: Comparative studies in ancient world empires, 137-207. Oxford: Oxford University Press. 
-. 2010. "Coin quality, coin quantity, and coin value in early China and the Roman world." American Journal of Numismatics 22, 93-118.

-. 2015. "State revenue and expenditure in the Han and Roman empires." In W. Scheidel (ed.), State power in ancient China and Rome, 150-180. Oxford: Oxford University Press.

-. 2017. "Slavery and forced labour in Early China and the Roman world." In H. J. Kim, F. Vervaet, and S. Adalı (eds.), Eurasian empires in antiquity and the early Middle Ages: Contact and exchange between the Graeco-Roman world, Inner Asia and China, 133-150. Cambridge: Cambridge University Press.

Scogin, H. T. Jr. 1990. "Between heaven and man: Contract and the state in Han dynasty China." Southern California Law Review 63.4, 1326-1404.

Selbitschka, A. 2018a. "Genuine prestige goods in mortuary contexts: Emulation in polychrome silk and Byzantine solidi from northern China." Asian Perspectives 57.1, 2-50.

-. 2018b. “'I write, therefore I am': Scribes, literacy, and identity in early China." Harvard Journal of Asiatic Studies 78.2, 413-477.

Shelach-Lavi, G. 2015. The archaeology of Early China: From prehistory to the Han dynasty. Cambridge: Cambridge University Press.

Shen, K., J. N. Crossley, and A. W. Lun. 1999. The nine chapters on the mathematical art: Companion and commentary. Oxford: Oxford University Press.

Shiji 史記 [The Scribe’s Records]. 1959. Composed by Sima Qian 司馬遷 (145 or 135-ca. 87 BCE). Beijing: Zhonghua shuju.

Shi Yang 石洋. 2018. “Qin Han shiqi jiedai de qixian yu shouxi zhouqi” 秦汉时期借贷的期限与 收息周期 [Time limits for repayment and frequencies of interest collection during the Qin and Han periods]." Zhonguo jingji shi yanjiu 中国经济史研究, no. 5, 16-29.

Shuihudi Qin mu zhujian zhengli xiaozu 睡虎地秦墓竹簡整理小組. 1990. Shuihudi Qin mu zhujian 睡虎地秦墓竹簡 [Bamboo slips from a Qin tomb at Shuihudi]. Beijing: Wenwu chubanshe.

Sun Wenbo 孙闻博. 2018. “Qin zhidao de lishixue tansuo: Yi zouxiang, xiuzhu yu yanxian yicun wei zhongxin” 秦直道的历史探索: 以走向、修筑与沿线遗存为中心 [A historical study of the Qin Direct Road: With a focus on its direction, construction, and archaeological remains along its route]. Zhongguo shi yanjiu dongtai 中国史研究动态, no. 3, 56-59.

Swann, N. L. 1950. Food and money in ancient China: The earliest economic history of China to $A D$ 25: Han Shu 24 with related texts, Han Shu 91 and Shih-Chi 129. Princeton, NJ: Princeton University Press.

Terpstra, T. 2019. Trade in the ancient Mediterranean: Private order and public institutions. Princeton, NJ: Princeton University Press.

-. 2020. "Roman technological progress in comparative context: The Roman Empire, Medieval Europe and Imperial China." Explorations in Economic History 75.

Thierry, F. 1993. "De la nature fiduciaire de la monnaie chinoise." Bulletin du Cercle d'Études Numismatiques 30, 1-12.

-. 1997. Monnaies chinoises. Vol. 1, L'Antiquité préimpériale. Paris: Bibliothèque Nationale de France.

-. 2001. "Sur les spécifités fondamentales de la monnaie chinoise." In A. Testart (ed.), Aux origines de la monnaie, 109-144. Paris: Errance.

-. 2003. Monnaies chinoises. Vol. 2, Des Qin aux Cinq dynasties. Paris: Bibliothèque Nationale de France.

-. 2017. Les monnaies de la Chine ancienne: Des origines à la fin de l'Empire. Paris: Belles Lettres.

Twitchett, D. C. 1970. Financial administration under the T'ang dynasty. Cambridge: University of Cambridge.

Vogel, H. U. 1996. "Zur Frage der Genauigkeit antiker Längenmaße und ihrer interkulturellen Zusammenhänge im Lichte chinesischer metrologischer Sachüberreste.” In R. S. Elkar, 
C. Neutsch, K. J. Roth, and J. H. Schawacht (eds.), Vom rechten Maß der Dinge: Beiträge zur Wirtschafts- und Sozialgeschichte. Festschrift für Harald Witthöft zum 65. Geburtstag, 1-32. St. Katharinen: Scripta Mercaturae.

-. 2006. "The diffusion and transmission of the rotary-fan winnowing machine from China to Europe: New findings and new questions." History of Technology 27, 1-41.

von Glahn, R. 2016. The economic history of China: From antiquity to the nineteenth century. Cambridge: Cambridge University Press.

-. 2020. "Modalities of the fiscal state in imperial China." Journal of Chinese History 中國歷史學刊 4.1, 1-29.

Wagner, D. B. 2001. The state and the iron industry in Han China. Copenhagen: Nordic Institute of Asian Studies.

-. 2008. Science and civilisation in China. Vol. 5, Chemistry and chemical technology. Part 11, Ferrous metallurgy. Cambridge: Cambridge University Press.

Wang, H. 2004. Money on the Silk Road: The evidence from eastern Central Asia to C. AD 800, including a catalogue of the coins collected by Sir Aurel Stein. London: British Museum Press.

-. 2007. "Official salaries and local wages at Juyan, north-west China, first century BCE to first century CE.” In J. Lucassen (ed.), Wages and currency: Global comparisons from antiquity to the twentieth century, 59-76. Bern: Peter Lang.

-. 2013. "Textiles as money on the Silk Road?" Journal of the Royal Asiatic Society 23.2, 165-174. Wang Yongbo 王永波. 2005. “Handai huangjin zhubi jiliang biaoji yanjiu” 汉代黄金铸币计量 标记研究 [A study on Han-era gold money measure marks]. Gudai wenming 古代文明, no. 4, 263-301.

Wang Zijin 王子今. 1994. Qin Han jiaotong shigao 秦漢交通史稿 [A study on the history of traffic during the Qin and Han periods]. Beijing: Zhonggong zhongyang dangxiao chubanshe.

-. 2002. “Han chu chachu guanyuan feifa shouru de zhidu” 漢初查處官員非法收入的制度 [Early Han regulations concerning officials' illegal means of income]. Zhengfa luntan 政法論壇, no. 5, 3-8.

Watanabe Shinichirō 渡辺信一郎. 2010. Chūgoku kodai no zaisei to kokka 中国古代の財政と 国家 [Finance and the state in ancient China]. Tokyo: Kyūko shoin.

Watson, B. 1993. Records of the Grand Historian: Han dynasty II. Revised ed. New York, NY: Columbia University Press.

Wilbur, C. M. 1943. Slavery in China during the Former Han dynasty, 206 BC-AD 25. Chicago, IL: Field Museum of Natural History.

Wu, X., A. Hein, Z. Jin, D. Wei, F. Huang, and X. Yin. 2019. "Resettlement strategies and Han imperial expansion into southwest China: A multimethod approach to colonialism and migration." Archaeological and Anthropological Sciences 11.12, 6751-6781.

Xie Guihua 谢桂华. 1989. “Hanjian he Han dai de quyong daishu zhidu” 汉简和汉代的取庸代 戍制度 [Han bamboo slips and the system of frontier service substitution during the Han period].” In Gansu sheng wenwu kaogu yanjiusuo 甘肃省文物考古研究所 (ed.), Qin Han jiandu lunwenji 秦汉简牍论文集, 77-112. Lanzhou: Gansu renmin chubanshe.

Xie Quanfa 謝全發. 2007. “Han dai zhaifa yanjiu” 漢代債法研究 [A study of Han-era debt law].” PhD diss., Xinan zhengfa daxue.

Yamada Katsuyoshi 山田勝芳. 1993. Shin Kan zaisei shūnyū no kenkyū 秦漢財政収入の研究 [A study on Qin and Han fiscal revenue]. Tokyo: Kyūko shoin.

Yang, J. 2015. "Transportation, boarding, lodging, and trade along the early Silk Road: A preliminary study of the Xuanquan manuscripts." Journal of the American Oriental Society 135.3, 421-432.

Yang Zhenhong 楊振紅. 2003. “Qin Han ‘mingtianzhai zhi” shuo: Cong Zhangjiashan Han jian kan Zhanguo Qin Han de tudi zhidu” 秦汉“名田宅制’说: 从张家山汉简看战国秦汉的土地制度 
[The 'mingtianzhai system' of the Qin and Han: The Han slips from Zhangjiashan as evidence for the systems of land tenure during the Warring States, Qin, and Han periods]. Zhongguo shi yanjiu 中国史研究, no. 3, 49-72.

-. 2008. “Cong xinchu jiandu kan Qin Han shiqi de tianzu zhengshou” 從新出簡牘看秦漢時期的 田租徵收 [Collection of the land tax in the Qin and Han periods as reflected in the newly excavated bamboo and wooden documents].” Jianbo 簡帛, no. 3, 331-342.

Yantie lun jiaozhu 鹽鐵論校注 [The Discourses on Salt and Iron with collated commentaries]. 1992. Composed by Huan Kuan 桓寬 (first century BCE). Commentaries compiled by Wang Liqi 王利器. Beijing: Zhonghua shuju.

Yates, R. D. S. 2001. "Slavery in early China: A socio-cultural approach." Journal of East Asian Archaeology 3.1, 283-331.

-. 2011. "Soldiers, scribes, and women: Literacy among the lower orders in early China." In F. Li and D. P. Branner (eds.), Writing and literacy in Early China: Studies from the Columbia Early China Seminar, 339-369. Seattle, WA: University of Washington Press.

-. 2014. "The changing status of slaves in the Qin-Han transition." In Y. Pines, G. Shelach, L. Falkenhausen, and R. D. S. Yates (eds.), Birth of an empire: The state of Qin revisited, 206223. Berkeley, CA: University of California Press.

Yü, Y. 1967. Trade and expansion in Han China: $A$ study in the structure of sino-barbarian economic relations. Berkeley, CA: University of California Press.

Zhang Jinguang 张金光. 2007. "Pubian shoutian zhi de zhongjie yu siyou diquan de xingcheng: Zhangjiashan Han jian yu Qin jian bijiao yanjiu zhi yi” 普遍授田制的终结与私有地权的 形成: 张家山汉简与秦简比较研究之一 [The end of the system of universal land allocation and the formation of private land ownership: A comparison between the Zhangjiashan Han bamboo slips and the Qin bamboo slips]. Lishi yanjiu 历史研究, no. 5, 49-65.

Zhang Xiande 张先得. 1985. “Ji gedi chutu de yuanxing jinbing: Jianlun Handai linzhi jin, matijin” 记各地出土的圆形金饼: 兼论汉代麟趾金、马蹄金 [Notes on round gold biscuits unearthed from various sites: A survey of Han-era Qilin toe and horse hoof gold pieces]. Wenwu 文物, no. $12,39-49$.

Zhang, Z. 2013. “Revisiting the AD 28 case from Juyan 居延: How was civil justice different from criminal justice in Han China?" Journal of Asian History 47.1, 51-79.

Zhongguo gonglu jiaotong shi bianshen weiyuanhui 中国公路交通史审委员会, ed. 1994. Zhongguo gudai daolu jiaotong shi 中国古代道路交通史 [A history of road transportation in ancient China]. Beijing: Renmin jiaotong chubanshe.

Zhu Degui 朱德贵 and Xia Hailan 夏海兰. 2013. “Qin Han ‘shaofu’ wenti zhiyi” 秦汉“少府”问题 质疑 [Addressing some questions concerning the Qin and Han 'Lesser Treasury']. Bianjiang jingji yu wenhua 边疆经济与文化, no. 12, 67-71. 